\title{
FLUXNET- $\mathrm{CH}_{4}$ SYNTHESIS ACTIVITY \\ Objectives, Observations, and Future Directions
}

Sara H. Knox, Robert B. Jackson, Benjamin Poulter, Gavin McNicol,

Etienne Fluet-Chouinard, Zhen Zhang, Gustaf Hugelius, Philippe Bousquet, Josep G. Canadell,

Marielle Saunois, Dario Papale, Housen Chu, Trevor F. Keenan, Dennis Baldocchi,

Margaret S. Torn, Ivan Mammarella, Carlo Trotta, Mika Aurela, Gil Bohrer,

David I. Campbell, Alessandro Cescatti, Samuel Chamberlain, Jiquan Chen, Weinan Chen,

Sigrid Dengel, Ankur R. Desai, Eugenie Euskirchen, Thomas Friborg, Daniele Gasbarra,

Ignacio Goded, Mathias Goeckede, Martin Heimann, Manuel Helbig, Takashi Hirano,

David Y. Hollinger, Hirokı Iwata, Minseok Kang, Janina Klatt, Ken W. Krauss, Lars Kutzbach,

Annalea lohila, Bhaskar Mitra, Timothy H. Morin, Mats B. Nilsson, Shuli Niu, Asko Noormets,

Walter C. Oechel, Matthias Peichl, Olli Peltola, Michele L. Reba, Andrew D. Richardson,

Benjamin R. K. Runkle, Youngryel Ryu, Torsten Sachs, Karina V. R. Schäfer, Hans Peter Schmid, Narasinha Shurpali, Oliver Sonnentag, Angela C. I. Tang, Masahito Ueyama, Rodrigo Vargas, Timo Vesala, Eric J. Ward, lisamarie Windham-Myers, Georg Wohlfahrt, and Donatella Zona

We describe a new coordination activity and initial results for

a global synthesis of eddy covariance $\mathrm{CH}_{4}$ flux measurements.

A tmospheric methane $\left(\mathrm{CH}_{4}\right)$ is the second-most important anthropogenic greenhouse gas following carbon dioxide $\left(\mathrm{CO}_{2}\right)$ (Myhre et al. 2013). The concentration of $\mathrm{CH}_{4}$ in the atmosphere today is about 2.5 times higher than in 1750 (Saunois et al. 2016a). The increase in atmospheric $\mathrm{CH}_{4}$ has arisen from human activities in agriculture, energy production, and waste disposal, and from changes in natural $\mathrm{CH}_{4}$ sources and sinks (Saunois et al. 2016a,b, 2017; Turner et al. 2019). Based on top-down atmospheric inversions, global $\mathrm{CH}_{4}$ emissions for the decade of 2003-12 were an estimated $\sim 420 \mathrm{Tg} \mathrm{C} \mathrm{yr}^{-1}$ (range 405-426 $\mathrm{Tg} \mathrm{C} \mathrm{yr}^{-1}$ ) (Saunois et al. 2016a). However, some analyses suggest that uncertainties in global $\mathrm{CH}_{4}$ sources and sinks are higher than those for $\mathrm{CO}_{2}$, and uncertainties from natural sources exceed those from anthropogenic emissions (Saunois et al. 2016a). In particular, the largest source of uncertainty in the global $\mathrm{CH}_{4}$ budget is related to emissions from wetlands and inland waters (Saunois et al. 2016a; Melton et al. 2013; Bastviken et al. 2011). Wetland $\mathrm{CH}_{4}$ emissions may contribute as much as $25 \%-40 \%$ of the global total and are a leading source of interannual variability in total atmospheric $\mathrm{CH}_{4}$ concentrations (Bousquet et al. 2006; Chen and Prinn 2006; Saunois et al. 2016a).

Direct, ground-based measurements of in situ $\mathrm{CH}_{4}$ fluxes with high measurement frequency are important for understanding the responses of $\mathrm{CH}_{4}$ fluxes to environmental factors including climate, 
AFFILIATIONS: KNOX-Department of Earth System Science, Stanford University, Stanford, California, and Department of Geography, The University of British Columbia, Vancouver, British Columbia, Canada; JACKSON-Department of Earth System Science, Woods Institute for the Environment, and Precourt Institute for Energy, Stanford University, Stanford, California; Poulter-Biospheric Sciences Laboratory, NASA Goddard Space Flight Center, Greenbelt, Maryland; MCNicol AND Fluet-ChOUINARD-Department of Earth System Science, Stanford University, Stanford, California; ZHANG-Department of Geographical Sciences, University of Maryland, College Park, College Park, Maryland; Hugelus-Department of Physical Geography, and Bolin Centre for Climate Research, Stockholm University, Stockholm, Sweden; BousQuet AND SAUNOIS-Laboratoire des Sciences du Climat et de l'Environnement, LSCE-IPSL, CEA-CNRS-UVSQ, Université Paris-Saclay, Gif-surYvette, France; CANADELL-Global Carbon Project, Oceans and Atmosphere, CSIRO, Canberra, Australian Capital Territory, Australia; PAPALE AND TROTTA-Dipartimento per la Innovazione nei Sistemi Biologici, Agroalimentari e Forestali, Università degli Studi della Tuscia, Largo dell'Università, Viterbo, Italy; CHU, TORN, AND DeNGEL-Earth and Environmental Sciences Area, Lawrence Berkeley National Lab, Berkeley, California; KeEnAN-Earth and Environmental Sciences Area, Lawrence Berkeley National Lab, and Department of Environmental Science, Policy and Management, University of California, Berkeley, Berkeley, California; BALDOCCHI and Chamberlain-Department of Environmental Science, Policy and Management, University of California, Berkeley, Berkeley, California; Mammarella - Institute for Atmospheric and Earth System Research/Physics, Faculty of Science, University of Helsinki, Helsinki, Finland; Aurela, Lohila, and Peltola-Finnish Meteorological Institute, Helsinki, Finland; BOHRER—Department of Civil, Environmental and Geodetic Engineering, The Ohio State University, Columbus, Ohio; CAMPBELL-School of Science, University of Waikato, Hamilton, New Zealand; Cescatti ANd Goded-European Commission, Joint Research Centre (JRC), Ispra, Italy; J. CHENDepartment of Geography, Environment, and Spatial Sciences, and Center for Global Change and Earth Observations, Michigan State, East Lansing, Michigan; W. Chen AND Niu-Key Laboratory of Ecosystem Network Observation and Modeling, Institute of Geographic Sciences and Natural Resources Research, Chinese Academy of Sciences, Beijing, China; Desal-Department of Atmospheric and Oceanic Sciences, University of Wisconsin-Madison, Madison, Wisconsin; EUSKIRCHEN - Institute of Arctic Biology, University of Alaska Fairbanks, Fairbanks, Alaska; FRIBORG-Department of Geosciences and Natural Resource Management, University of Copenhagen, Copenhagen, Denmark; GASBARRA-Department of Vegetal Biology, University of Napoli Federico II, and Institute for Mediterranean Agricultural and Forest Systems, CNR, Naples, Italy; GoECKEDEMax Planck Institute for Biogeochemistry, Jena, Germany; HElMANN-Max Planck Institute for Biogeochemistry, Jena, Germany, and Institute for Atmosphere and Earth System Research/Physics, Faculty of Science, University of Helsinki, Helsinki, Finland; HeLBIGSchool of Geography and Earth Sciences, McMaster University, Hamilton, Ontario, and Département de Géographie, Université de Montréal, Montreal, Quebec, Canada; HIRANO-Research Faculty of Agriculture, Hokkaido University, Sapporo, Japan; HoluINGERNorthern Research Station, Forest Service, USDA, Durham, New Hampshire; IWATA-Department of Environmental Sciences, Shinshu
University, Matsumoto, Nagano, Japan; KANG—National Center for AgroMeteorology, Seoul, South Korea; KLATT-Institute of Meteorology and Climate Research, Karlsruhe Institute of Technology, Garmisch-Partenkirchen, Germany; KRAUSS AND WARD-Wetland and Aquatic Research Center, U.S. Geological Survey, Lafayette, Louisiana; KUTZBACH — Institute of Soil Science, Center for Earth System Research and Sustainability, Universität Hamburg, Hamburg, Germany; Mitra AND NoORMETS-Department of Ecosystem Science and Management, Texas A\&M University, College Station, Texas; MORIN-Department of Environmental Resources Engineering, State University of New York College of Environmental Science and Forestry, Syracuse, New York; NILSSON AND PEICHL-Department of Forest Ecology and Management, Swedish University of Agricultural Sciences, Umeå, Sweden; OECHEL-Department of Biology, San Diego State University, San Diego, California, and Department of Physical Geography, University of Exeter, Exeter, United Kingdom; ReBA-Delta Water Management Research Service, Agricultural Research Service, USDA, Jonesboro, Arkansas; RICHARDSONSchool of Informatics, Computing, and Cyber Systems, and Center for Ecosystem Science and Society, Northern Arizona University, Flagstaff, Arizona; RUNKLE-Department of Biological and Agricultural Engineering, University of Arkansas, Fayetteville, Arkansas; Ryu-Department of Landscape Architecture and Rural Systems Engineering, Seoul National University, Seoul, South Korea; SACHSGFZ German Research Centre for Geoscience, Potsdam, Germany; SCHÄFER-Department of Biological Sciences, Rutgers, The State University of New Jersey, Newark, New Jersey; SCHMID-Atmospheric Environmental Research, Institute of Meteorology and Climatology, Karlsruhe Institute of Technology, Garmisch-Partenkirchen, Germany; SHURPALI-Biogeochemistry Research Group, Department of Biological and Environmental Sciences, University of Eastern Finland, Kuopio, Finland; SonNenTAG—Département de Géographie and Centre d'Études Nordiques, Université de Montréal, Montreal, Quebec, Canada; TANG-Sarawak Tropical Peat Research Institute, Kota Samarahan, Sarawak, Malaysia; UeYAMAGraduate School of Life and Environmental Sciences, Osaka Prefecture University, Sakai, Japan; VARGAS - Department of Plant and Soil Sciences, University of Delaware, Newark, Delaware; VESALA-Institute for Atmospheric and Earth System Research/Physics, Faculty of Science, and Institute for Atmospheric and Earth System Research/ Forest Sciences, Faculty of Agriculture and Forestry, University of Helsinki, Helsinki, Finland; Windham-Myers-Water Mission Area, U.S. Geological Survey, Menlo Park, California; WohlfaHrT-Department of Ecology, University of Innsbruck, Innsbruck, Austria; ZonA-Department of Biology, San Diego State University, San Diego, California, and Department of Animal and Plant Sciences, University of Sheffield, Sheffield, United Kingdom

CORRESPONDING AUTHOR: Sara Knox,

saraknox.knox@gmail.com

The abstract for this article can be found in this issue, following the table of contents.

DOI:I0.II75/BAMS-D-18-0268.I

A supplement to this article is available online (I0.II75/BAMS-D-I8-0268.2)

In final form II June 2019

(C)2019 American Meteorological Society

For information regarding reuse of this content and general copyright information, consult the AMS Copyright Policy. 
for providing validation datasets for the land surface models used to infer global $\mathrm{CH}_{4}$ budgets, and for constraining $\mathrm{CH}_{4}$ budgets. Eddy covariance (EC) flux towers measure real-time exchange of gases such as $\mathrm{CO}_{2}, \mathrm{CH}_{4}$, water vapor, and energy between the land surface and the atmosphere. The EC technique has emerged as a widespread means of measuring trace gas exchange because it provides direct and near-continuous ecosystem-scale flux measurements without disturbing the soil or vegetation (Baldocchi 2003; Aubinet et al. 2012). There are more than 900 reported active and historical flux tower sites globally and approximately 7,000 site years of data collected (Chu et al. 2017). While most of these sites measure $\mathrm{CO}_{2}$, water vapor, and energy exchange, the development of new and robust $\mathrm{CH}_{4}$ sensors has resulted in a rapidly growing number of $\mathrm{CH}_{4} \mathrm{EC}$ measurements (Baldocchi 2014; Morin 2018), primarily in natural and agricultural wetlands (Petrescu et al. 2015).

Since the late 1990s, with a growing number of long-term, near-continuous EC measurements, the EC community has been well coordinated for integrating and synthesizing $\mathrm{CO}_{2}$, water vapor and energy fluxes. This cross-site coordination resulted in the development of regional flux networks for Europe [EuroFlux, CarboEurope, and Integrated Carbon Observing System (ICOS)], Australia (OzFlux), North and South America (AmeriFlux, Large Biosphere Amazon, Fluxnet-Canada/Canadian Carbon Program, and MexFlux), Asia (AsiaFlux, ChinaFlux, KoFlux, and U.S.-China Carbon Consortium (USCCC)], and globally, FLUXNET (Papale et al. 2012; Baldocchi 2014). The resulting FLUXNET database (http:// fluxnet.fluxdata.org/) has been used extensively to evaluate satellite measurements, inform Earth system models, generate data-driven $\mathrm{CO}_{2}$ flux products, and provide answers to a broad range of questions about atmospheric fluxes related to ecosystems, land use and climate (Pastorello et al. 2017). FLUXNET has grown steadily over the past 25 years, enhancing our understanding of carbon, water and energy cycles in terrestrial ecosystems (Chu et al. 2017).

Similar community efforts and syntheses for $\mathrm{CH}_{4}$ remain limited in part because EC measurements for $\mathrm{CH}_{4}$ fluxes were rarer until recently. Whereas the earliest EC measurements of $\mathrm{CO}_{2}$ fluxes date back to the late 1970s and early 1980s (Desjardins 1974; Anderson et al. 1984), the first $\mathrm{EC} \mathrm{CH}_{4}$ flux measurements only began in the 1990s (Verma et al. 1992; Shurpali and Verma 1998; Fan et al. 1992; Kim et al. 1999), with reliable, easy-to-deploy field sensors only becoming available in the past decade or so. $\mathrm{EC}^{\mathrm{CH}_{4}}$ flux measurements became more feasible with advances in sensor development, such as tunable diode laser absorption spectrometers, that allowed researchers to measure previously undetectable trace gas fluxes with higher signal to noise ratios (Rinne et al. 2007; McDermitt et al. 2011). After these new sensors were commercialized, and low-power, low-maintenance open-path sensors were developed that could be operated by solar panels in remote locations, the number of $\mathrm{CH}_{4}$ flux tower measurements increased substantially (Baldocchi 2014; Morin 2018). The rapidly growing number of $\mathrm{EC} \mathrm{CH}_{4}$ flux measurements presents new opportunities for FLUXNET-type analyses and syntheses of ecosystem-scale $\mathrm{CH}_{4}$ flux observations.

This manuscript describes initial results from a new coordination activity for flux tower $\mathrm{CH}_{4}$ measurements organized by the Global Carbon Project (GCP) in collaboration with regional flux networks and FLUXNET. The goal of the activity is to develop a global database for $\mathrm{EC} \mathrm{CH}_{4}$ observations to answer regional and global questions related to $\mathrm{CH}_{4}$ cycling. Here, we describe the objectives of the FLUXNET$\mathrm{CH}_{4}$ activity, provide an overview of the current geographic and temporal coverage of $\mathrm{CH}_{4}$ flux measurements globally, present initial analyses exploring time scales of variability, uncertainty, trends, and drivers of $\mathrm{CH}_{4}$ fluxes across 60 sites, and discuss future research opportunities for examining controls on $\mathrm{CH}_{4}$ emissions and reducing uncertainties in the role of wetlands in the global $\mathrm{CH}_{4}$ cycle.

\section{FLUXNET- CH $_{4}$ SYNTHESIS OBJECTIVES} AND TASKS. This activity is part of a larger GCP effort to establish and better constrain the global methane budget ( $w w w . g l o b a l c a r b o n p r o j e c t . o r g$ /methanebudget/index.htm), and is designed to develop a $\mathrm{CH}_{4}$ database component in FLUXNET for a global synthesis of $\mathrm{CH}_{4}$ flux tower data. To this end, we are surveying, assembling, and synthesizing data from the EC community, in coordination with regional networks, including AmeriFlux's 2019 "Year of Methane" (http://ameriflux.lbl.gov/year-of -methane/year-of-methane/), FLUXNET initiatives, and other complementary activities. In particular, this work is being carried out in parallel with the EU's Readiness of ICOS for Necessities of Integrated Global Observations (RINGO) project, which is working to standardize protocols for flux calculations, quality control and gap-filling for $\mathrm{CH}_{4}$ fluxes (Nemitz et al. 2018). Methane-specific protocols are needed because of the added complexities and high variability of $\mathrm{CH}_{4}$ flux measurements and dynamics (Nemitz et al. 2018). 
Our approach is to include all currently available and future $\mathrm{CH}_{4}$ flux tower observations in a global $\mathrm{CH}_{4}$ database, including freshwater, coastal, natural, and managed ecosystems, as well as upland ecosystems that may be measuring $\mathrm{CH}_{4}$ uptake by soils. The initiative is open to all members of the EC community. Database compilation began in 2017 and is ongoing. Data from sites in the Americas can be submitted to AmeriFlux (http://ameriflux.lbl.gov/data/how -to-uploaddownload-data/); otherwise, data can be submitted to the European Fluxes Database Cluster (www.europe-fluxdata.eu/home/sites-list).

In addition to many applications, an ultimate goal of the FLUXNET- $\mathrm{CH}_{4}$ activity is to generate a publicly available, open-access, data-driven global $\mathrm{CH}_{4}$ emissions product using similar machine-learning-based approaches used for $\mathrm{CO}_{2}$ fluxes (Jung et al. 2009; Tramontana et al. 2016). The product will be based on mechanistic factors associated with $\mathrm{CH}_{4}$ emissions and new spatiotemporal information on wetland area and dynamics for constraining $\mathrm{CH}_{4}$-producing areas. This gridded product will provide an independent bottom-up estimate of global wetland $\mathrm{CH}_{4}$ emissions to compare with estimates of global $\mathrm{CH}_{4}$ emissions from land surface models and atmospheric inversions. Recent work has shown the potential to upscale EC $\mathrm{CH}_{4}$ flux observations across northern wetlands, with predictive performance comparable to previous studies upscaling net $\mathrm{CO}_{2}$ exchange (Peltola et al. 2019); however, our focus is on a globally gridded product.

The near-continuous, high-frequency nature of EC measurements also offers significant promise for improving our understanding of ecosystem-scale $\mathrm{CH}_{4}$ flux dynamics. As such, this synthesis also aims to investigate the dominant controls on net ecosystemscale $\mathrm{CH}_{4}$ fluxes from hourly to interannual time scales across wetlands globally, and to characterize scale-emergent, nonlinear, and lagged processes of $\mathrm{CH}_{4}$ exchange.

Methane is produced during decomposition under anaerobic or reducing conditions and is transported to the atmosphere via plant-mediated transport, ebullition, and diffusion (Bridgham et al. 2013). During transport, $\mathrm{CH}_{4}$ can pass through unsaturated soil layers and be consumed or oxidized by aerobic bacteria (Wahlen 1993). Process-based biogeochemical models developed and applied at site, regional, and global scales simulate these individual processes with varying degrees of complexity (Bridgham et al. 2013; Melton et al. 2013; Poulter et al. 2017; Castro-Morales et al. 2018; Grant and Roulet 2002). The large range in predicted wetland $\mathrm{CH}_{4}$ emissions rates suggests that there is both substantial parameter and structural uncertainty in large-scale $\mathrm{CH}_{4}$ flux models, even after accounting for uncertainties in wetland areas (Poulter et al. 2017; Saunois et al. 2016a; Melton et al. 2013; Riley et al. 2011). A global EC $\mathrm{CH}_{4}$ database and associated environmental variables can help constrain the parameterization of process-based biogeochemistry models (Saunois et al. 2016a; Bridgham et al. 2013; Oikawa et al. 2017). Furthermore, a key challenge is evaluating globally applicable process-based $\mathrm{CH}_{4}$ models at a spatial scale comparable to model grid cells (Melton et al. 2013; Riley et al. 2011). A globally gridded wetland $\mathrm{CH}_{4}$ emissions product upscaled from EC fluxes can help resolve this issue by providing a scale-appropriate model evaluation dataset. As such, the global $\mathrm{CH}_{4}$ database and gridded product will also be used to parameterize and benchmark the performance of land surface models of global $\mathrm{CH}_{4}$ emissions, providing a unique opportunity for informing and validating biogeochemical models.

METHODS. Based on a survey of the EC community (announced via the fluxnet-community @george.lbl.gov and AmeriFlux-Community@lbl.gov listservs), information available in regional networks and FLUXNET, and the scientific literature, we estimate that at least 200 sites worldwide are currently applying the $\mathrm{EC}$ method for $\mathrm{CH}_{4}$ flux measurements (Fig. 1). Here we focus on findings from across 60 of the $\sim 110$ sites currently committed to participating in our FLUXNET- $\mathrm{CH}_{4}$ activity [Table A1 in the appendix and Table ES1 in the online supplemental material (https://doi.org/I0.II75/BAMS-D-18-0268.2)]. Data from this initial set of sites were selected because they were publicly available or were contributed directly by site principal investigators (PIs). We will continue to engage the EC community more broadly and expand the database in the future.

Data standardization, gap-filling, and partitioning. We used similar data processing procedures as FLUXNET to standardize and gap-fill measurements, and in the case of net $\mathrm{CO}_{2}$ exchange, partition fluxes across sites (http://fluxnet.fluxdata.org/data/aboutdata/data -processing-I0I-pipeline-and-procedures/). Standard quality assurance and quality control of the data were first performed by site PIs. In nearly all cases, data collected by the local tower teams were first submitted to the data archives hosted by the regional flux networks, where data are prescreened and formatted based on the regional network data protocols. Data from the regional networks then entered our flux processing procedure. 


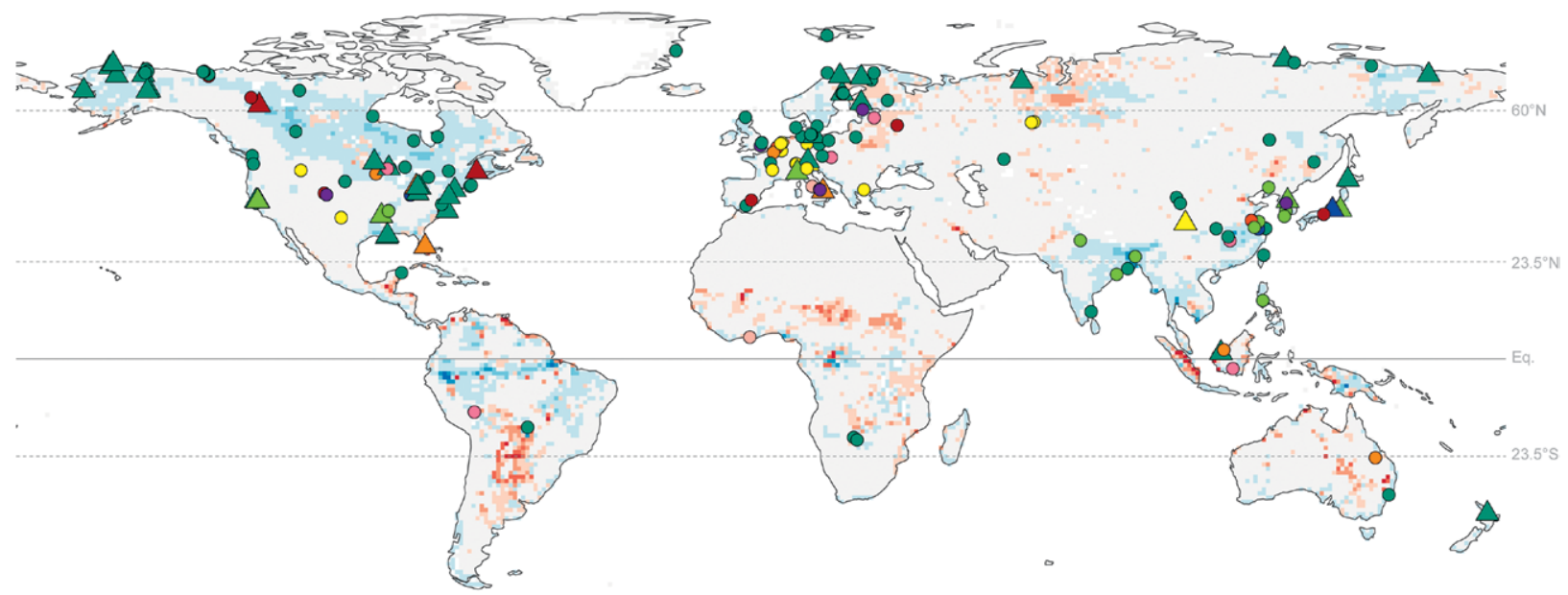

\section{IGBP Site Types}

- Cropland - Other

- Cropland - Rice

- Deciduous Broadleaf Forest

Evergreen Broadleaf Forest

- Evergreen Needleleaf Forest
Grassland
- Mixed Forest
- Urban \& Built-Up
- Waterbodies
- Permanent Wetlands

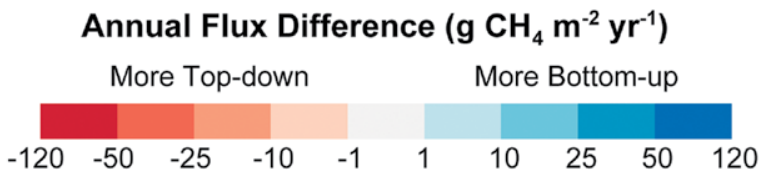

FIG. I. Location of the $\mathbf{2 0 0}$ tower sites that report eddy covariance $\mathbf{C H}_{4}$ flux measurements worldwide. Triangles indicate sites from which data are included in this manuscript, with circles indicating additional flux towers measuring $\mathrm{CH}_{4}$ emissions. The colors of the markers represent the vegetation type based on the International Geosphere-Biosphere Programme (IGBP) definition. See Table ESI for a list of sites, their characteristics, and years of operation. Sites are overlaid over a map of the differences between the average $\mathrm{CH}_{4}$ emissions over 2000-10 between top-down and bottom-up wetland $\mathrm{CH}_{4}$ estimates. Top-down estimates are represented by the natural fluxes inventoried in NOAA's CarbonTracker (www.esrl.noaa.gov/gmd/ccgg/carbontracker-ch4/). Bottom-up emissions were produced from an ensemble of II Earth system model simulations (Poulter et al. 20I7).

Within our processing procedure, data were first checked for obvious problems including unit errors, spikes, and out-of-range values based on visualization of the data and statistical metrics. Next, the data were filtered, gap-filled, and partitioned. Friction velocity $\left(u_{\star}\right)$ filtering, based on relating nighttime $\mathrm{CO}_{2}$ fluxes to $u_{*}$, was implemented using the REddyProc package (Wutzler et al. 2018) for R statistical software (R Core Team 2018, version 3.5.0), although in a few cases $u_{\star}$ filtering was performed by the site PIs. Gaps in meteorological variables including air temperature $(\mathrm{TA})$, incoming shortwave $\left(\mathrm{SW}_{\mathrm{IN}}\right)$ and longwave $\left(\mathrm{LW}_{\mathrm{IN}}\right)$ radiation, vapor pressure deficit (VPD), pressure (PA), precipitation $(P)$, and wind speed (WS) were filled with ERA-Interim (ERA-I) reanalysis data (Vuichard and Papale 2015). Gaps in $\mathrm{CO}_{2}$ and latent and sensible heat fluxes were filled using the marginal distribution sampling method (Reichstein et al. 2005) using the REddyProc package (Wutzler et al. 2018). Net $\mathrm{CO}_{2}$ fluxes were partitioned into gross primary production (GPP) and ecosystem respiration (ER) using both the nighttime (Reichstein et al. 2005) and daytime (Lasslop et al. 2010) approaches also implemented in REddyProc (Wutzler et al. 2018).
There are as yet no standards for gap-filling $\mathrm{CH}_{4}$ flux measurements and this is an active and ongoing area of research (Nemitz et al. 2018). Gaps in $\mathrm{CH}_{4}$ fluxes were filled using artificial neural networks (ANNs), as they have shown good performance for gap-filling $\mathrm{CH}_{4}$ flux data (Dengel et al. 2013; Knox et al. 2015; Morin et al. 2014a; Nemitz et al. 2018; Goodrich et al. 2015). Details of the ANN routine are provided in Knox et al. (2016) and are summarized here briefly. The ANN routine was optimized for both generalizability and representativeness. To facilitate representativeness, explanatory data were divided into a maximum of 15 data clusters using the $k$-means algorithm. To avoid biasing toward conditions with better flux data coverage (e.g., summer and daytime), data used to train, test, and validate the ANN were proportionately sampled from these clusters. Several neural network architectures of increasing complexity were tested, ranging from one hidden layer with the number of nodes equal to the number of explanatory data variables $(N)$ to two hidden layers with $1.5 \mathrm{~N}$ and $0.75 \mathrm{~N}$ nodes, respectively. The architecture of each neural network was initialized 10 times with random starting weights, and the initialization resulting in the lowest mean sampling 
error was selected. The simplest architecture, whereby additional increases in complexity resulted in $<5 \%$ reduction in mean squared error, was chosen and the prediction saved. This procedure was repeated with 20 resamplings of the data, and missing half hours were filled using the median prediction. A standard set of variables available across all sites were used to gap-fill $\mathrm{CH}_{4}$ fluxes (Dengel et al. 2013), including $\mathrm{TA}, \mathrm{SW}_{\mathrm{IN}}, \mathrm{WS}, \mathrm{PA}$, and sine and cosine functions to represent seasonality. These meteorological variables were selected since they are relevant to $\mathrm{CH}_{4}$ exchange and were gap-filled using the ERA-I reanalysis data. Other variables related to $\mathrm{CH}_{4}$ exchange such as water table depth (WTD) or soil temperature (TS) were not included as explanatory variables as they were not available across all sites or had large gaps that could not be filled using the ERA-I reanalysis data. These missing data for variables highlight some of the key challenges in standardizing $\mathrm{CH}_{4}$ gap-filling methods across sites and emphasize the need for standardized protocols of auxiliary measurements across sites (cf. "Future research directions and needs" section) (Nemitz et al. 2018; Dengel et al. 2013). ANN gapfilling was performed using MATLAB (MathWorks 2018, version 9.4.0).

Annual $\mathrm{CH}_{4}$ budgets represent gap-filled, halfhourly fluxes integrated over an entire year or growing season. If fluxes were only measured during the growing season, we assumed that fluxes outside of this period were negligible, although we acknowledge that cold season fluxes can account for as much as $\sim 13 \%-50 \%$ of the annual $\mathrm{CH}_{4}$ emissions in some locations (Zona et al. 2016; Treat et al. 2018b; Helbig et al. 2017a; Kittler et al. 2017).

Uncertainty estimation. ANNs were also used to estimate annual gap-filled and random uncertainty in $\mathrm{CH}_{4}$ flux measurements (Richardson et al. 2008; Moffat et al. 2007; Anderson et al. 2016; Knox et al. 2018). Here, we focus on assessing the random error, but a full assessment of total flux measurement error also requires quantifying systematic error or bias (Baldocchi 2003). Systematic errors, due to incomplete spectral response, lack of nocturnal mixing, submesoscale circulations, and other factors are discussed elsewhere (Baldocchi 2003; Peltola et al. 2015) and are the focus of other ongoing initiatives.

Random errors in EC fluxes follow a double exponential (Laplace) distribution with a standard deviation varying with flux magnitude (Richardson et al. 2012, 2006). Model residuals of gap-filling algorithms such as ANNs provide a reliable, and conservative "upper limit," estimate of the random flux uncertainty (Moffat et al. 2007; Richardson et al. 2008). For half-hourly $\mathrm{CH}_{4}$ flux measurements, random error was estimated using the residuals of the median ANN predictions. At each site, the probability density function (PDF) of the random flux measurement error more closely followed a double-exponential (Laplace) rather than normal (Gaussian) distribution, with the root-mean-square error (RMSE) for the Laplace distribution fitted to the PDF of random errors consistently lower than the normal distributed error. From half-hourly flux measurements, random error can also be estimated using the daily differencing approach (Richardson et al. 2012). Random error estimates $[\sigma(\delta)]$, as expressed as the standard deviation of the doubleexponential distribution with scaling parameter $\beta$, where $\sigma(\delta)=\sqrt{2} \beta$ (Richardson et al. 2006), were found to be nearly identical using the two approaches $\left[\sigma(\delta)_{\text {model_residual }}=1.0 \times \sigma(\delta)_{\text {daily_differencing }}+1.21 ; r^{2}=0.97\right.$, $p<0.001]$, supporting the use of the model residual approach for estimating random error. As discussed below, $\sigma(\delta)$ scaled linearly with the magnitude of $\mathrm{CH}_{4}$ fluxes at nearly all sites. To quantify random uncertainty of cumulative fluxes, we used a Monte Carlo simulation that randomly draws 1,000 random errors for every original measurement using $\sigma(\delta)$ binned by flux magnitude, and then computed the variance of the cumulative sums (Anderson et al. 2016). For gap-filled values, the combined gap-filling and random uncertainty was calculated from the variance of the cumulative sums of the 20 ANN predictions (Anderson et al. 2016; Oikawa et al. 2017; Knox et al. 2015). The annual cumulative uncertainty at $95 \%$ confidence was estimated by adding the cumulative gap-filling and random measurement uncertainties in quadrature (Richardson and Hollinger 2007; Anderson et al. 2016). Note that when reporting mean or median annual $\mathrm{CH}_{4}$ fluxes across sites, error bars represent the standard error.

Wavelet-based time-scale decomposition. Methane fluxes are highly dynamic and vary across a range of time scales (Sturtevant et al. 2016; Koebsch et al. 2015). For example, in wetlands with permanent inundation, the seasonal variation of $\mathrm{CH}_{4}$ exchange is predominantly controlled by temperature and plant phenology (Chu et al. 2014; Sturtevant et al. 2016). Ecosystem $\mathrm{CH}_{4}$ exchange also varies considerably at both longer (e.g., interannual; Knox et al. 2016; Rinne et al. 2018) and shorter (e.g., weeks, days, or hours; Koebsch et al. 2015; Hatala et al. 2012; Schaller et al. 2018) time scales. Wavelet decomposition is a particularly useful tool for investigating scale in geophysical 
and ecological analysis (Cazelles et al. 2008; Torrence and Compo 1998), because it can characterize both the time scale and location of patterns and perturbations in the data. Partitioning variability across temporal scales can help to isolate and characterize important processes (Schaller et al. 2018).

The maximal overlap discrete wavelet transform (MODWT) was used to decompose the time scales of variability in gap-filled $\mathrm{CH}_{4}$ flux measurements, as described in Sturtevant et al. (2016). The MODWT allows the time series to be decomposed into the detail added from progressively coarser to finer scales and either summed or treated individually to investigate patterns across scales. We reconstructed the detail in the fluxes for dyadic scales $1\left(2^{1}\right.$ measurements $\left.=1 \mathrm{~h}\right)$ to $14\left(2^{14}\right.$ measurements $=341$ days). Since patterns generated by ecological processes tend to occur over a scale range rather than at one individual scale, the detail over adjacent scales were summed to analyze four general time scales of variation (Sturtevant et al. 2016). These time scales included the "hourly" scale (1-2 h) representing perturbations such the passage of clouds overhead and turbulent scales up to the spectral gap, the "diel" scale ( $4 \mathrm{~h}$ to 1.3 days) encompassing the diel cycles in sunlight and temperature, the "multiday" scale (2.7 to 21.3 days) reflecting synoptic weather variability or fluctuations in water levels, and the "seasonal" scale (42.7 to 341 days) representing the annual solar cycle and phenology. Data were wavelet decomposed into the hourly, diel, and multiday scales using the Wavelet Methods for Time Series Analysis (WMTSA) Wavelet Toolkit in MATLAB.

Statistical analysis. We tested for significant relationships between log-transformed annual $\mathrm{CH}_{4}$ emissions and a number of covariates using linear mixed-effects models as described in Treat et al. (2018b). The predictor variables of $\mathrm{CH}_{4}$ flux we evaluated included: biome or ecosystem type (categorical variables), and continuous biophysical variables including mean seasonal WTD, mean annual soil and air temperature ( $T_{\mathrm{MST}}$ and $T_{\mathrm{MAT}}$, respectively), net ecosystem exchange (NEE), GPP, and ER. When considering continuous variables, we focused on freshwater wetlands for comparison with previous $\mathrm{CH}_{4}$ synthesis activities. Soil temperature was measured between 2 and $25 \mathrm{~cm}$ below the surface in different studies. The results below are presented for GPP and ER covariates that are partitioned using the nighttime flux partitioning algorithm (Wutzler et al. 2018; Reichstein et al. 2005), although similar findings were obtained using daytime partitioned estimates. Additionally, individual sites or site years were excluded when gaps in measurements exceeded two consecutive months, which explains the differences in the number of sites and site years in the "Environmental controls on annual $\mathrm{CH}_{4}$ emissions across freshwater wetland sites" section below.

Mixed-effects modeling was used because of the potential bias of having measurements over several years, with site included as a random effect in the analysis (Treat et al. 2018b). The significance of individual predictor variables was evaluated using a $\chi^{2}$ test against a null model using only site as a random variable (Bates et al. 2015), with both models fit without reduced maximum likelihood. For multiple linear regression models, we used the model selection process outlined in Zuur et al. (2009). To incorporate annual cumulative uncertainty when assessing the significance of trends and differences in annual $\mathrm{CH}_{4}$ fluxes across biomes and ecosystem types, we used a Monte Carlo simulation that randomly draws 1,000 annual cumulative uncertainties for each estimate of annual $\mathrm{CH}_{4}$ flux. For each random draw the significance of the categorical variable was tested using a $\chi^{2}$ test against the null model with only site as a random variable. We report the marginal $r^{2}\left(r_{m}^{2}\right)$, which describes the proportion of variance explained by the fixed factors alone (Nakagawa and Schielzeth 2013). The mixed-effects modeling was implemented using the lmer command from the lme4 package (Bates et al. 2015) for R statistical software.

RESULTS AND DISCUSSION. Geographic and temporal coverage of eddy covariance $\mathrm{CH}_{4}$ flux measurements. We identified 200 sites worldwide that are applying the EC method for $\mathrm{CH}_{4}$ (Fig. 1; Table ES1); wetlands (including natural, managed, and restored wetlands) comprise the majority of sites (59\%), with rice agriculture (10\%) as the second-most represented vegetation type. The predominance of wetland and rice paddy sites in the database is unsurprising because many studies are designed to target ecosystems expected to have relatively large $\mathrm{CH}_{4}$ emissions. However, there are also sites in ecosystems that are typically smaller sources or even sinks of $\mathrm{CH}_{4}$ such as upland forests (13\%) and grasslands (8\%). Additionally, six sites ( $3 \%)$ are urban, with another five sites measuring $\mathrm{CH}_{4}$ fluxes from open water bodies. Although identified sites span all continents except Antarctica, the majority are concentrated in North America and Europe, with a growing number of sites in Asia (Fig. 1; Table ES1).

Measurements of $\mathrm{CH}_{4}$ fluxes cover a broad range of climates and a large fraction of wetland habitats (Fig. 2), with the tropics and tropical wetlands notably 
underrepresented. As discussed below (see "Future research directions and needs" section), one important goal of FLUXNET and the regional networks is to increase site representativeness and extend measurements in undersampled regions. Increasing the number of tropical sites is particularly important for $\mathrm{CH}_{4}$ because more than half of global $\mathrm{CH}_{4}$ emissions are thought to come from this region (Saunois et al. 2016a; Dean et al. 2018). Furthermore, compared to northern wetlands, their biogeochemistry remains relatively poorly understood (Mitsch et al. 2009; Pangala et al. 2017). We expect the number of $\mathrm{CH}_{4}$ flux sites and their geographic and temporal coverage to continue to increase, as has occurred through time for $\mathrm{CO}_{2}$, water vapor, and energy flux measurements in FLUXNET (Pastorello et al. 2017; Chu et al. 2017).

Long-term $\mathrm{CH}_{4}$ flux time series are key to understanding the causes of year-to-year variability and

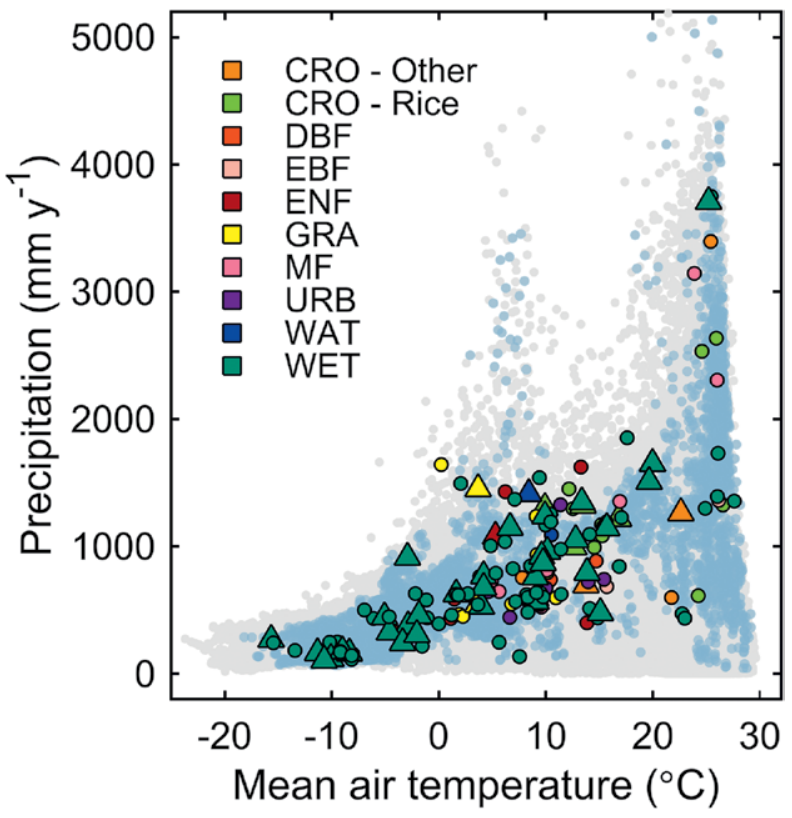

FIG. 2. Distribution of sites by mean annual air temperature and precipitation. Tower locations are shown as circles or triangles (see Fig. I), with vegetation type in color based on the IGBP definitions (CRO = croplands; DBF = deciduous broadleaf forests; $E B F=$ evergreen broadleaf forests; ENF = evergreen needleleaf forests; GRA = grasslands; MF = mixed forests; URB = urban and built-up lands; WAT = water bodies; $W E T=$ permanent wetlands). Gray dots represent annual mean temperature and total precipitation from the CRU TS 3.10 gridded climate dataset over the entire landmass (Harris et al. 2014), whereas blue dots represent grid cells with $\mathbf{> 2 5} \%$ wetland fraction as estimated using the Global Lakes and Wetlands Database (Lehner and Döll 2004). Temperature and precipitation grid cells included in this figure were averaged from 1981 to $201 \mathrm{I}$, at $0.5^{\circ}$ resolution. trends in fluxes (Chu et al. 2017; Euskirchen et al. 2017; Pugh et al. 2018). The longest continuous record of $\mathrm{CH}_{4}$ flux measurements, from a fen in Finland (Rinne et al. 2018), is now $\sim 14$ years and ongoing (Table ES1). Three other sites have measurements exceeding 10 years; however, the median length is 5 years, with most sites established from 2013 onward (Table ES1). Longer time series are also important for both exploring the short- and long-term effects of extreme events on fluxes and tracking the response of disturbed or restored ecosystems over time (Pastorello et al. 2017). Furthermore, they can help address new and emerging science questions, such as quantifying $\mathrm{CH}_{4}$ feedbacks to climate with rising temperatures and associated changes in ecosystem composition, structure and function (Helbig et al. 2017a,b; Dean et al. 2018), and the role of wetland emissions in atmospheric $\mathrm{CH}_{4}$ variability (McNorton et al. 2016; Poulter et al. 2017).

$\mathrm{CH}_{4}$ fluxes and trends across biomes and ecosystem types. Half-hourly and annual net $\mathrm{CH}_{4}$ fluxes for the 60 sites currently included in the database exhibited strong variability across sites (Figs. 3 and 4). Across the dataset, the mean half-hourly $\mathrm{CH}_{4}$ flux was greater than the median flux, indicating a positively skewed distribution with infrequent, large emissions (Fig. 3a), similar to findings from chamber-based syntheses (Olefeldt et al. 2013; Turetsky et al. 2014). Mean and median $\mathrm{CH}_{4}$ fluxes were smaller at higher latitudes and larger at lower latitudes (Fig. 3b), comparable again to trends in $\mathrm{CH}_{4}$ fluxes observed in predominantly chamber-based syntheses (Bartlett and Harriss 1993; Turetsky et al. 2014; Treat et al. 2018b).

The continuous nature of EC flux measurements is well suited for quantifying annual ecosystem-scale $\mathrm{CH}_{4}$ budgets, along with accumulated uncertainty (cf. "Gap-filling performance and uncertainty quantification" section). Annual estimates of net $\mathrm{CH}_{4}$ flux for each of the 60 sites in the flux tower database ranged from $-0.2 \pm 0.02 \mathrm{~g} \mathrm{C} \mathrm{m}^{-2} \mathrm{yr}^{-1}$ for an upland forest site to $114.9 \pm 13.4 \mathrm{~g} \mathrm{C} \mathrm{m}^{-2} \mathrm{yr}^{-1}$ for an estuarine freshwater marsh (Rey-Sanchez et al. 2018), with fluxes exceeding $40 \mathrm{~g} \mathrm{C} \mathrm{m}^{-2} \mathrm{yr}^{-1}$ at multiple sites (Fig. 4b). These emissions are of a considerably broader range and have much higher annual values than in an earlier synthesis by Baldocchi (2014), which included published values from 13 sites (Fig. 4a); median annual $\mathrm{CH}_{4}$ fluxes $( \pm \mathrm{SE})$ in that study were $6.4 \pm 1.9 \mathrm{~g} \mathrm{C} \mathrm{m}^{-2} \mathrm{yr}^{-1}$, compared with $10.0 \pm 1.6 \mathrm{~g} \mathrm{C} \mathrm{m}^{-2} \mathrm{yr}^{-1}$ for our expanded database. Annual $\mathrm{CH}_{4}$ sums in our database were positively skewed, with skewness increasing with additional observations due largely to the inclusion of 
high $\mathrm{CH}_{4}$-emitting freshwater marsh sites (Fig. 4).

As suggested from Fig. 3b, annual wetland $\mathrm{CH}_{4}$ emissions differed significantly among biomes, even when considering accumulated uncertainty [average Monte Carlo $\chi^{2}=13.4$ (12.1-14.7, 95\% confidence interval), degrees of freedom $(\mathrm{df})=3, p<0.05]$ (Table 1). Median $\mathrm{CH}_{4}$ emissions were significantly lower for tundra wetlands $\left(2.9 \pm 1.3 \mathrm{~g} \mathrm{C} \mathrm{m}^{-2} \mathrm{yr}^{-1}\right)$ than temperate wetlands (27.4 $\left.\pm 3.4 \mathrm{~g} \mathrm{C} \mathrm{m}^{-2} \mathrm{yr}^{-1}\right)$. Higher $\mathrm{CH}_{4}$ emissions were observed from subtropical/tropical wetlands $\left(43.2 \pm 11.2 \mathrm{~g} \mathrm{C} \mathrm{m}^{-2} \mathrm{yr}^{-1}\right)$, based on only three site years of data; however, emphasizing the need for additional flux tower measurements in the tropics.

Whereas annual boreal/taiga wetland $\mathrm{CH}_{4}$ emissions were comparable to values reported in a recent synthesis of predominantly chamber-based $\mathrm{CH}_{4}$ flux measurements (Treat et al. 2018b), our tower-based measurements are $~ 50 \%$ lower and over 6 times higher for tundra and temperate wetlands, respectively (Table 1). The inconsistencies highlighted in Table 1 not only reflect the differences in the number and location of sites between datasets, but also the discrepancies resulting from different measurement
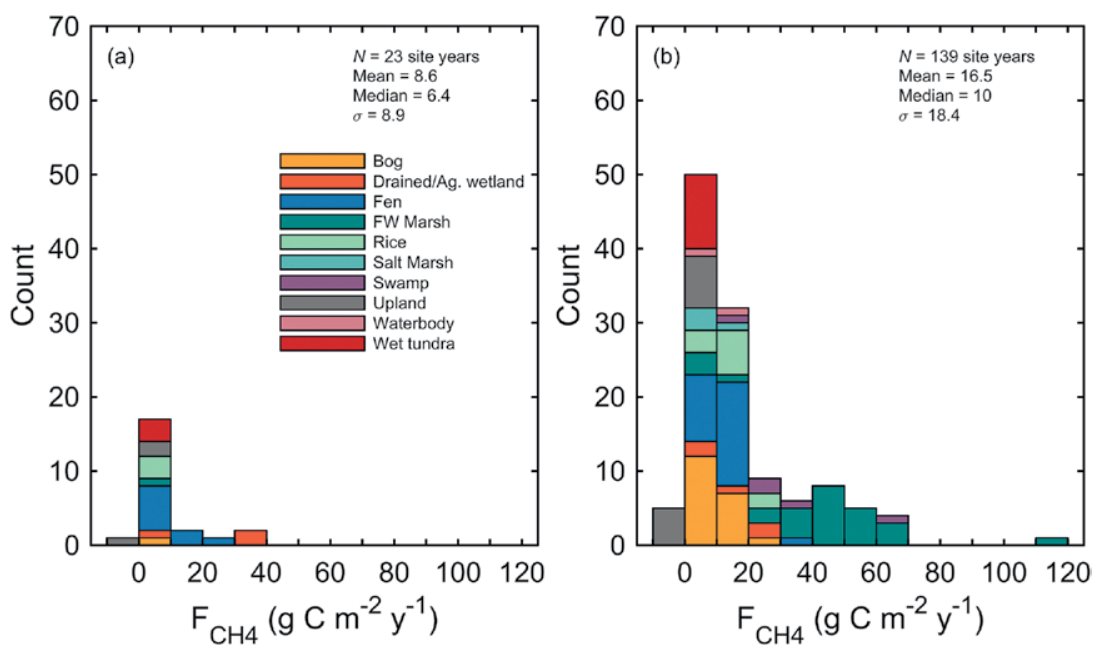

Fig. 4. (a) Histogram of annual $\mathrm{CH}_{4}$ fluxes $\left(\mathrm{F}_{\mathrm{CH}} ; \mathrm{g} \mathrm{C} \mathrm{m}^{-2} \mathrm{yr}^{-1}\right)$ measured with eddy covariance and published in the synthesis by Baldocchi (2014), and (b) histogram of our annual $\mathrm{CH}_{4}$ fluxes including additional site years of data estimated from the $\mathbf{6 0}$ sites listed in Table Al. techniques. Several studies have noted considerable differences in $\mathrm{CH}_{4}$ emissions measured using EC and chamber techniques, with estimates from chambers often higher than those from the EC measurements (Schrier-Uijl et al. 2010; Hendriks et al. 2010; Meijide et al. 2011; Krauss et al. 2016). This distinction highlights the need for additional studies investigating the systematic differences caused by the different spatial and temporal sampling footprints of these methods (Krauss et al. 2016; Morin et al. 2017; Windham-Myers et al. 2018; $\mathrm{Xu}$ et al. 2017). Characterizing discrepancies between measurement techniques may also help constrain bottom-up estimates of $\mathrm{CH}_{4}$ emissions and reduce the disagreement of $\sim 15 \mathrm{Tg} \mathrm{C} \mathrm{yr}^{-1}$ between bottom-up (139 $\left.\mathrm{Tg} \mathrm{CH}_{4} \mathrm{yr}^{-1}\right)$ and top-down $\left(125 \mathrm{Tg} \mathrm{CH}_{4} \mathrm{yr}^{-1}\right)$ estimates of $\mathrm{CH}_{4}$ emissions from natural wetlands (Saunois et al. 2016a).

Annual $\mathrm{CH}_{4}$ emissions also differed significantly across ecosystems [average Monte Carlo $\chi^{2}=45.5(39.3-50.1)$, $\mathrm{df}=9, p<0.001$; Fig. 5], with median fluxes highest for freshwater marshes $(43.2 \pm$ 
TABLE I. Number of site years and characteristics of $\mathrm{CH}_{4}$ fluxes $\left(\mathrm{g} \mathrm{C} \mathrm{m}^{-2} \mathrm{yr}^{-1}\right)$ currently included in the database. Fluxes are compared with measurements reported in a recent synthesis of predominantly chamberbased $\mathrm{CH}_{4}$ flux measurements. Biome type was extracted from Olson et al. (200I) using site coordinates and includes tundra, boreal/taiga, temperate, and tropical/subtropical. Wetland $\mathrm{CH}_{4}$ emissions differed significantly across biomes, with letters indicating significant differences $(a=0.05)$ among biomes. Note that similar to our tower only dataset, values from Treat et al. (2018b) represent measured annual fluxes derived from a smaller dataset where measurements were made in the growing season and nongrowing season.

\begin{tabular}{|c|c|c|c|c|c|}
\hline Biome & $\begin{array}{c}\text { No. of } \\
\text { site years }\end{array}$ & $\begin{array}{l}\text { Median annual } \\
\mathrm{CH}_{4} \text { flux }\end{array}$ & $\begin{array}{c}\text { 25th } \\
\text { percentile }\end{array}$ & $\begin{array}{c}\text { 75th } \\
\text { percentile }\end{array}$ & References \\
\hline \multirow{4}{*}{ Tundra } & 10 & 2.9 & 1.8 & 4.2 & This study_All sites \\
\hline & 10 & $2.9^{a}$ & 1.8 & 4.2 & This study-Wetlands \\
\hline & 31 & 5.6 & 1.0 & 11.4 & Treat et al. (2018b)_All sites \\
\hline & 26 & 6.3 & 3.0 & 16.4 & Treat et al. (2018b) -Wetlands \\
\hline \multirow{4}{*}{ Boreal and taiga } & 35 & 8.3 & 4.1 & 10.9 & This study-All sites \\
\hline & 30 & $9.5^{\mathrm{ab}}$ & 6.0 & 11.3 & This study-Wetlands \\
\hline & 68 & 13.1 & 3.5 & 23.7 & Treat et al. (2018b)_All sites \\
\hline & 67 & 13.2 & 3.6 & 23.7 & Treat et al. (2018b) —Wetlands \\
\hline \multirow{4}{*}{ Temperate } & 72 & 16.4 & 7.9 & 35.9 & This study-All sites \\
\hline & 47 & $27.4^{\mathrm{b}}$ & 10.0 & 47.3 & This study-Wetlands \\
\hline & 27 & 4.3 & 0.3 & 41.7 & Treat et al. (2018b)—All sites \\
\hline & 25 & 5.3 & 0.8 & 42.2 & Treat et al. (2018b) -Wetlands \\
\hline \multirow{4}{*}{$\begin{array}{l}\text { Tropical and } \\
\text { subtropical }\end{array}$} & 3 & 43.2 & 20.0 & 46.8 & This study-All sites \\
\hline & 3 & $43.2^{\mathrm{ab}}$ & 20.0 & 46.8 & This study-Wetlands \\
\hline & - & - & - & - & Treat et al. (2018b)_All sites \\
\hline & - & - & - & - & Treat et al. (2018b) -Wetlands \\
\hline
\end{tabular}

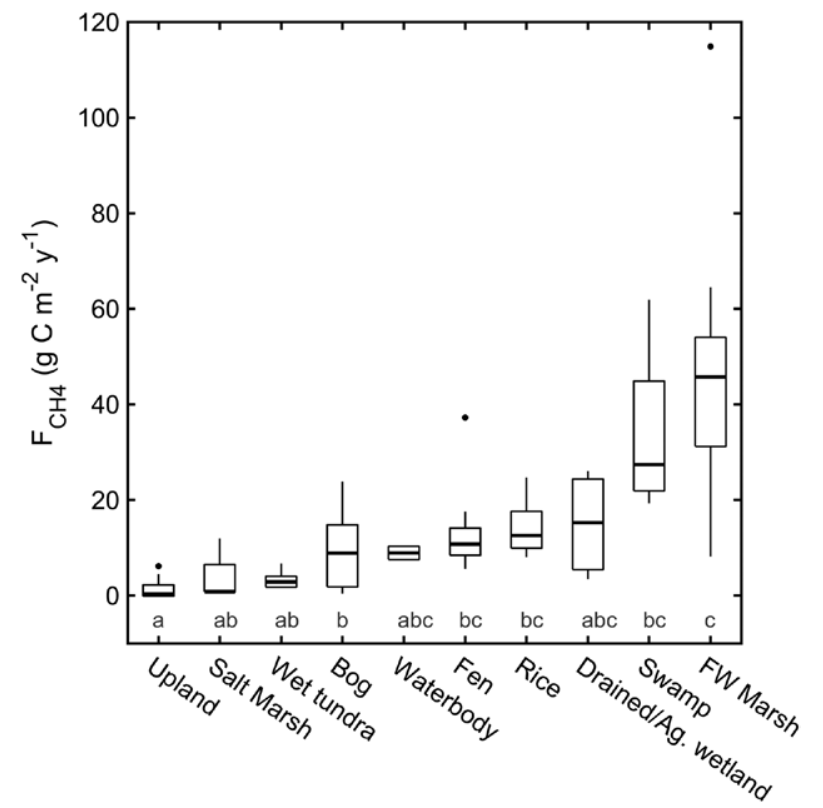

Fig. 5. Annual $\mathrm{CH}_{4}$ fluxes $\left(F_{\mathrm{CH} 4} ; \mathrm{g} \mathrm{C} \mathrm{m}^{-2} \mathrm{yr}^{-1}\right)$ among ecosystem types for the $\mathbf{6 0}$ sites currently included in the database (Table Al). Letters indicate significant differences $(a=0.05)$ among ecosystem types. Median value, first quartile, and third quartile are presented in the boxes, and dots represent outliers, which are defined as observations more than 1.5 times the interquartile range away from the top or bottom of the box. $\left.4.2 \mathrm{~g} \mathrm{C} \mathrm{m}^{-2} \mathrm{yr}^{-1}\right)$ and lowest for upland ecosystems (1.3 $\left.\pm 0.7 \mathrm{~g} \mathrm{C} \mathrm{m}^{-2} \mathrm{yr}^{-1}\right)$. Treat et al. (2018b) also observed the highest annual emissions in marshes and reported a similar median value for temperate marshes (49.6 $\left.\mathrm{g} \mathrm{C} \mathrm{m}^{-2} \mathrm{yr}^{-1}\right)$. Wet tundra and bogs had significantly lower annual emissions than marshes (Fig. 5), which in part reflects their presence in colder boreal and tundra systems, as well as differences in vegetation type, nutrient status, and hydrological regime (Treat et al. 2018b). Low median $\mathrm{CH}_{4}$ emission was observed from salt marshes in our dataset $\left(0.8 \pm 2.9 \mathrm{~g} \mathrm{C} \mathrm{m}^{-2} \mathrm{yr}^{-1}\right)$, because high sulfate concentrations inhibit methanogenesis (Poffenbarger et al. 2011; Holm et al. 2016). Even drained wetlands converted to agricultural land can be large sources of $\mathrm{CH}_{4}$ associated with seasonal flooding (Fig. 5). Median annual $\mathrm{CH}_{4}$ flux from rice was $12.6 \pm$ $1.6 \mathrm{~g} \mathrm{C} \mathrm{m}^{-2} \mathrm{yr}^{-1}$, which is slightly lower than the IPCC default value of $15 \mathrm{~g} \mathrm{C} \mathrm{m}^{-2} \mathrm{yr}^{-1}$ (Sass 2003).

Environmental controls on annual $\mathrm{CH}_{4}$ emissions across freshwater wetland sites. Using an integrated $\mathrm{CH}_{4}$ flux database, we can begin to investigate the factors associated with varying $\mathrm{CH}_{4}$ emissions across sites. We explored the effects of WTD, $T_{\mathrm{MST}}$ or $T_{\mathrm{MAT}}$ NEE, GPP, and ER on annual $\mathrm{CH}_{4}$ flux. At global scales, 
$T_{\text {MAT }}$ and $T_{\text {MST }}$ were the most important predictors of annual $\mathrm{CH}_{4}$ flux across wetland sites ( $p<0.001$ for each), with the fixed factor of $T_{\mathrm{MAT}}$ or $T_{\mathrm{MST}}$ explaining $\sim 65 \%$ of the variation in $\log$ transformed annual $\mathrm{CH}_{4}$ emission (Figs. 6a,b). Previous synthesis studies also observed a significant, but weaker, relationship between soil temperature and average $\mathrm{CH}_{4}$ emissions across sites, explaining $<15 \%$ of the variation in $\mathrm{CH}_{4}$ flux in those studies (Olefeldt et al. 2013; Yvon-Durocher et al. 2014). However, our findings are consistent with numerous site-level studies that report a strong correlation between wetland $\mathrm{CH}_{4}$ emissions and temperature, with nearly $95 \%$ of all EC studies reporting a significant relationship between temperature and $\mathrm{CH}_{4}$ flux (Morin 2018). Across sites, Peltola et al. (2019) found that the most impor-

tant predictor in a random forest model used to upscale $\mathrm{EC} \mathrm{CH}_{4}$ emissions across northern latitudes was temperature, again highlighting the importance of temperature in regulating $\mathrm{CH}_{4}$ emissions within and across sites.

Water table depth has also commonly been identified as a key control on $\mathrm{CH}_{4}$ emissions (Turetsky et al. 2014; Bubier et al. 2005), because higher water levels often inhibit oxygen availability and lower the soil reduction potential, making methanogenesis more thermodynamically favorable. Although predominantly chamber-based wetland $\mathrm{CH}_{4}$ syntheses have found a positive relationship between WTD and average or annual $\mathrm{CH}_{4}$ emissions across sites (Olefeldt et al. 2013; Turetsky et al. 2014; Treat et al. 2018b), we observed no significant relationship between mean WTD and annual $\mathrm{CH}_{4}$ flux across all sites $\left(\chi^{2}=0.2, \mathrm{df}=1, p=0.66, N_{\text {sites }}=20, N_{\text {site_yr }}=46\right)$, even when considering $\mathrm{WTD}^{2}$ or WTD ${ }^{3}$ (Olefeldt et al. 2013). However, if we consider only sites where WTD was below the soil surface for part or all of the year (Fig. 6c, solid circles), we did observe a significant relationship with WTD $(p<0.05)$. Conversely, $\mathrm{CH}_{4}$ emissions for permanently inundated sites showed no significant relationship with WTD (Fig. 6c, open circles) $\left(\chi^{2}=0.5, \mathrm{df}=1, p=0.50, N_{\text {sites }}=13, N_{\text {site_yr }}=19\right)$. This result supports the finding that wetlands that are permanently inundated or exhibit little variation in WTD tend to show weak to no correlation between WTD and $\mathrm{CH}_{4}$ emissions (Chu et al. 2014; JackowiczKorczyński et al. 2010; Rinne et al. 2007; Christensen et al. 2003); in contrast, wetlands with lower and more variable water levels often have a significant relationship between WTD and $\mathrm{CH}_{4}$ emissions (Bubier et al. 2005; Treat et al. 2007). However, only half of the sites currently included in the database report water table position, and given the importance of WTD in regulating $\mathrm{CH}_{4}$ exchange, it is critical to ensure that WTD is measured across all sites.

Gross primary production and ER were both significant positive predictors of annual $\mathrm{CH}_{4}$ flux $\left(\chi^{2}=21.3, \mathrm{df}=1, p<0.001, r_{m}^{2}=0.29\right.$ and $\chi^{2}=17.1$, $\mathrm{df}=1, p<0.001, r_{m}^{2}=0.25$, respectively, $N_{\text {sites }}=26$, $\left.N_{\text {site_yr }}=64\right)$, although there was no significant relationship between NEE and annual $\mathrm{CH}_{4}$ flux $\left(\chi^{2}=0.9\right.$, $\left.\mathrm{df}=1, p=0.33, N_{\text {sites }}=2, N_{\text {site_yr }}=64\right)$. However, when considering GPP or ER in a multiple linear regression model with $T_{\mathrm{MST}}$, including interaction terms (Chu 


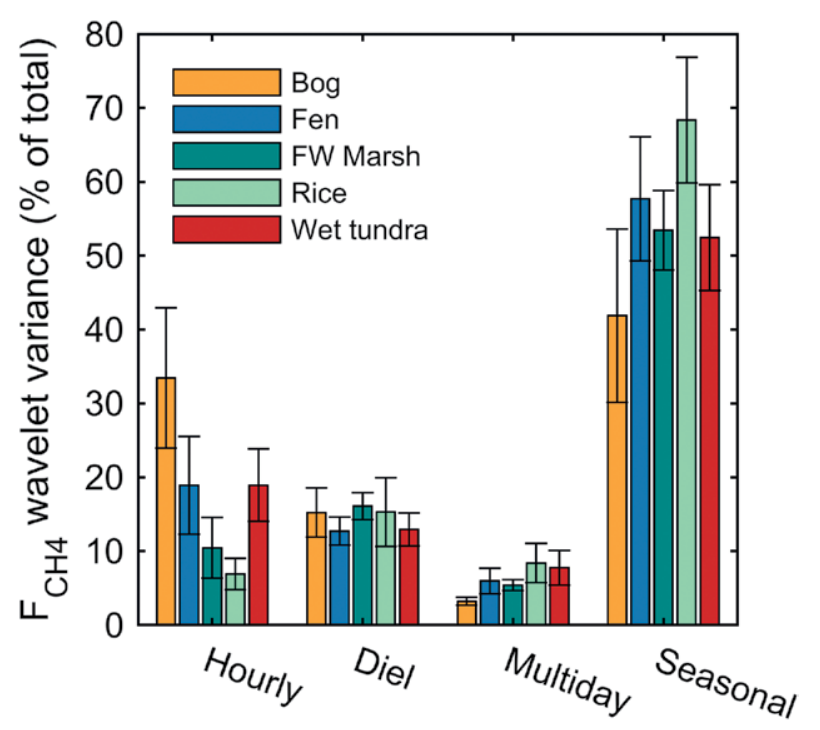

Time Scale

FIG. 7. Variance of $\mathrm{CH}_{4}$ flux $\left(\mathrm{F}_{\mathrm{CH} 4}\right)$ wavelet coefficients across time scales, as a percentage of the total variance, averaged by wetland type. Error bars represent the standard error. Note that only ecosystem types with at least 6 sites are shown here, including bogs, fens, freshwater (FW) marshes, rice paddies, and wet tundra.

et al. 2014), neither GPP nor ER were significant, suggesting that the observed relationship with GPP or ER was due to covariation with soil temperature and, possibly, other environmental drivers.

The strong temperature dependence of ecosystemscale $\mathrm{CH}_{4}$ emissions we observed across wetland sites is in line with the high temperature sensitivity of $\mathrm{CH}_{4}$ emissions found across microbial to ecosystem scales (Yvon-Durocher et al. 2014). $\mathrm{CH}_{4}$ emissions also have a higher temperature dependence than ER, such that the ratio of $\mathrm{CH}_{4}$ to $\mathrm{CO}_{2}$ emissions was found to increase markedly with seasonal increases in temperature (Yvon-Durocher et al. 2014). Similarly, we observed a significant increase in the ratio of annual $\mathrm{CH}_{4}$ to ER along geographic temperature gradients, ranging from $0.4 \%$ to $7.9 \%$, with a median value of $2.8 \%$ across the dataset (Fig. 6d). This relationship suggests that warming may result in a greater relative contribution of $\mathrm{CH}_{4}$ to total carbon emissions from wetland ecosystems. With a growing FLUXNET $\mathrm{CH}_{4}$ database, it will be possible to further explore the dominant controls on $\mathrm{CH}_{4}$ fluxes within and across ecosystem types, as well as further investigate the temperature dependence of ecosystem-scale $\mathrm{CH}_{4}$ exchange (Schipper et al. 2014; Arcus et al. 2016; Yvon-Durocher et al. 2014).

Time scales of variability. Methane fluxes exhibited strong variability over a range of time scales, with the variation across time scales differing between wetland types (Fig. 7). As observed previously (Sturtevant et al. 2016), the seasonal time scale dominated $\mathrm{CH}_{4}$ flux variability across wetland types, but was most pronounced in rice paddies, which have a distinct growing season, and least pronounced in bogs (Fig. 7). Across ecosystem types, variation was lowest at the multiday scale, although multiday $\mathrm{CH}_{4}$ flux variation was slightly greater in rice paddies and wet tundra, potentially indicating greater water table fluctuations (Sturtevant et al. 2016), particularly at rice paddy sites, which are subject to seasonal drainage (Knox et al. 2016; Runkle et al. 2019). Whereas some studies report a strong diel pattern in $\mathrm{CH}_{4}$ emissions from wetlands and rice paddies (Knox et al. 2016; Chu et al. 2014; Morin et al. 2014b; Kim et al. 1999), others have found little or no diel variation (Rinne et al. 2018; Jackowicz-Korczyński et al. 2010; Yagi and Minami 1990; Nadeau et al. 2013). Across wetland types, diel variation was greatest in freshwater marshes (Fig. 7), which is consistent with the observations that the vegetation at sites with a strong diel cycle of $\mathrm{CH}_{4}$ emissions is typically dominated by species with convective gas flow such as Phragmites australis or Typha spp. (Brix et al. 1992; Chanton et al. 1993). Bogs, fens, and wet tundra showed the greatest variation at the hourly scale (Fig. 7). This is likely in part due to typically lower fluxes at these sites as hourly perturbations of turbulent time series are largely dominated by noise (Hollinger and Richardson 2005), as well as the fact that near-surface turbulence and short-term pressure fluctuations can strongly influence $\mathrm{CH}_{4}$ exchange in these peat dominated ecosystems (Nadeau et al. 2013; Sachs et al. 2008).

\section{Gap-filling performance and uncertainty quantification.} The performance of the neural networks varied strongly across sites (Fig. 8). Model $r^{2}$, calculated from the median ANN prediction and observed fluxes at each site, ranged from $\sim 0$ to 0.92 across sites, with a median value of 0.41 . Across sites, ANN performance was strongly linked to the percentage of total variance at diel and seasonal scales $\left(r^{2}=0.69\right.$, $p<0.001$ ), indicating that across the wide range of observed flux magnitudes, sites with a more distinct seasonal and diel pattern tended to be more predictable (Fig. 8). There was also a significant negative relationship between model $\mathrm{r}^{2}$ and the percentage of total variance at the hourly scale across sites $\left(r^{2}=0.72\right.$, $p<0.001$ ), because, as noted previously, hourly perturbations are largely dominated by noise (Hollinger and Richardson 2005).

Knowledge of the random errors in half-hourly flux measurements is not only important for 
evaluating the uncertainty in cumulative fluxes (e.g., daily, monthly, or annual) and comparing fluxes across tower sites, but it also needed to incorporate information about random flux errors in model-data synthesis activities (Richardson et al. 2006). As noted above, random flux error more closely followed a Laplace rather than Gaussian distribution. Within sites, $\sigma(\delta)$ was not constant, but rather nearly always scaled with the magnitude of $\mathrm{CH}_{4}$ fluxes (Fig. 9a), as predicted from theory (Richardson et al. 2006). As observed for other fluxes (Richardson et al. 2006), both the slope and intercept of this relationship varied among sites, and depending on the sign of the flux (Fig. 9a). Across sites, random flux error therefore scaled linearly with the magnitude of mean $\mathrm{CH}_{4}$ flux $\left(r^{2}=0.86, p<0.001\right)$, even when excluding the two highest $\mathrm{CH}_{4}$-emitting sites $\left(r^{2}=0.46, p<0.001\right)$ (Fig. 9b). Whereas closed-path $\mathrm{CH}_{4}$ analyzers have been found to have lower random errors and instrument noise compared with open-path sensors (Peltola et al. 2014), there was no clear evidence of a systematic effect of the influence of closed- versus open-path sensors on random errors across sites (Fig. 9).

The total annual cumulative uncertainty in $\mathrm{CH}_{4}$ fluxes, including both random and gap-filling errors, ranged from \pm 0.01 to $\pm 13.4 \mathrm{~g} \mathrm{C} \mathrm{m}^{-2} \mathrm{yr}^{-1}$, with a median value of $\pm 1.0 \mathrm{~g} \mathrm{C} \mathrm{m}^{-2} \mathrm{yr}^{-1}$ at $95 \%$ confidence (Fig. 10a). Relative error decreased exponentially with flux magnitude, ranging from $1.5 \%$ to $60 \%$ in most cases (Fig. 10b), although a few sites where annual $\mathrm{CH}_{4}$ sums were near zero had relative errors exceeding 200\% (data not shown). The highest relative errors therefore tended to be associated with low $\mathrm{CH}_{4}$-emitting sites, such as upland sites and bogs, and the lowest relative errors were generally associated with high $\mathrm{CH}_{4}$-emitting sites such as freshwater marshes (Fig. 10b).

\section{FUTURE RESEARCH DIRECTIONS AND} NEEDS. Better quantification of $\mathrm{CH}_{4}$ sources and sinks will improve estimates of regional and global $\mathrm{CH}_{4}$ budgets and reduce uncertainties in the $\mathrm{CH}_{4}$ cycle. In this general

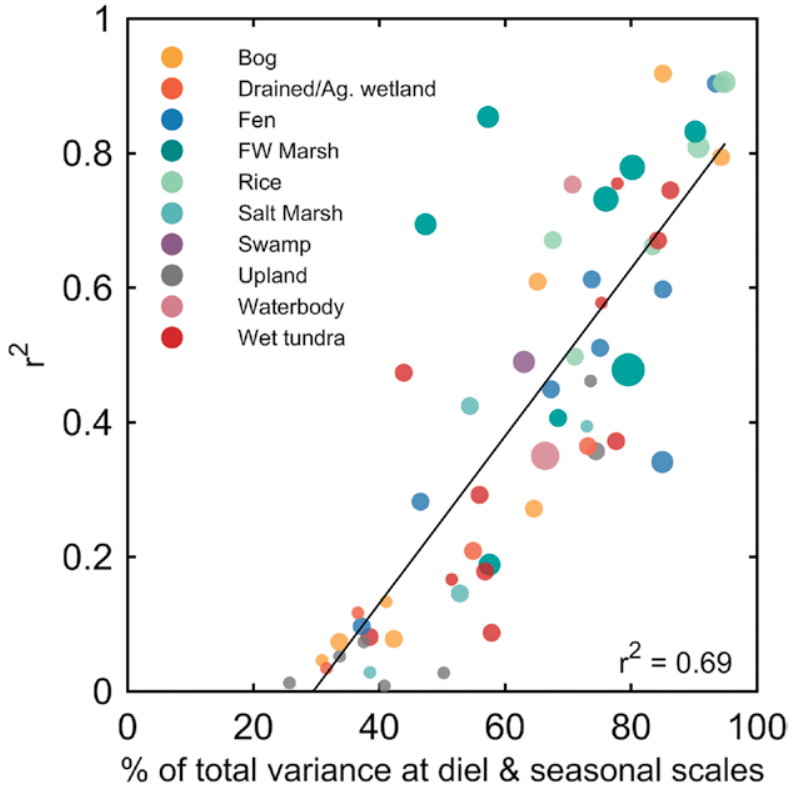

FIG. 8. Relationship between the correlation coefficient $\left(r^{2}\right)$ calculated from the median ANN prediction and observed $\mathrm{CH}_{4}$ fluxes at each site and the percentage of total variance at diel and seasonal scales $\left(r^{2}=0.69\right.$, $p<0.001$ ). Each site is color coded by ecosystem type. Sizes of the dots are proportional to the magnitude of mean $\mathrm{CH}_{4}$ flux, where flux magnitude was aggregated into 10 bins for plotting.
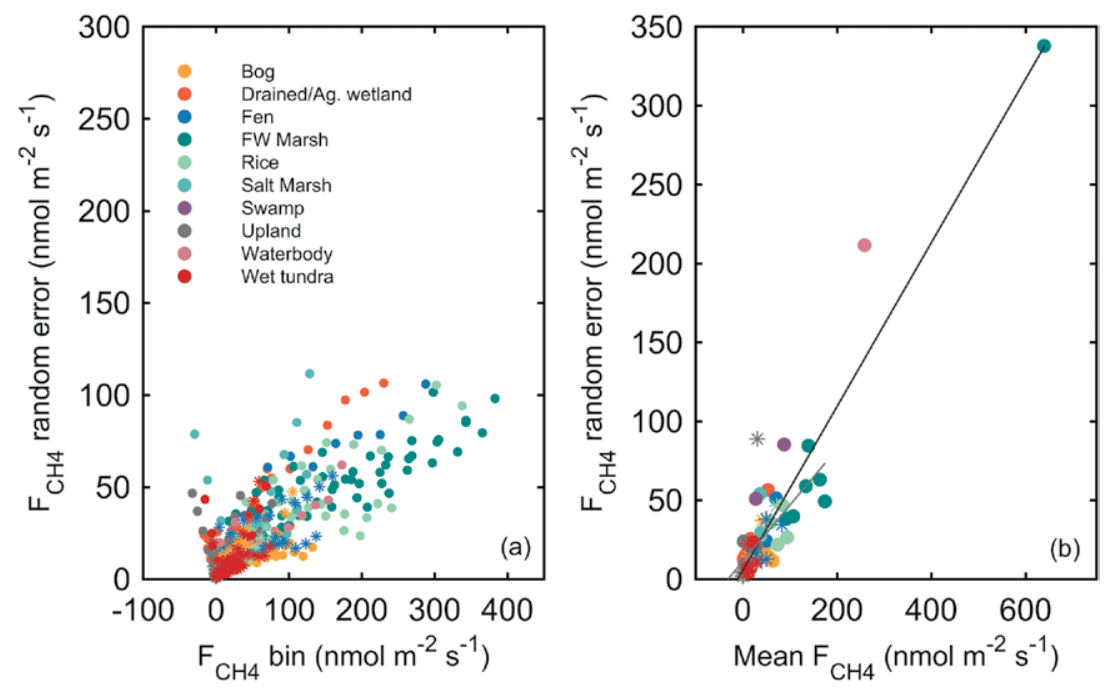

FIG. 9. (a) Scaling of $F_{\mathrm{CH} 4}$ random flux measurement error $[\sigma(\delta)]$ with flux magnitude for all sites with a significant linear relationship between random error and flux magnitude ( $95 \%$ of all sites). Data at each site were placed into 10 bins (Oikawa et al. 2017). (b) Scaling of $F_{\mathrm{CH} 4}$ random flux measurement error, characterized by the standard deviation of the double-exponential distribution $[\sigma(\delta)]$, with mean flux magnitude across sites. There was a significant linear relationship between $\sigma(\delta)$ and the magnitude of mean $\mathrm{CH}_{4}$ flux $\left[\sigma(\delta)=0.5 \times F_{\mathrm{CH} 4}+5.9, r^{2}=0.86, p<0.001\right]$, even when excluding the two highest $\mathrm{CH}_{4}$-emitting sites $\left[\sigma(\delta)=0.4 \times \mathrm{F}_{\mathrm{CH} 4}+\right.$ II.3, $\left.r^{2}=0.46, p<0.00 I\right]$. Note that circles represent sites with open-path $\mathrm{CH}_{4}$ analyzers while asterisks represent sites with closed-path sensors. 
context, high-frequency observations of ecosystem-scale $\mathrm{CH}_{4}$ emissions should help constrain bottom-up $\mathrm{CH}_{4}$ budgets, improve our understanding of the environmental factors controlling $\mathrm{CH}_{4}$ fluxes, and inform and validate land surface models used to estimate global $\mathrm{CH}_{4}$ fluxes. Unlike well-established efforts synthesizing $\mathrm{CO}_{2}$, water vapor, and energy observations, no such global data synthesis or initiative previously existed for $\mathrm{CH}_{4}$. The database presented here addresses this gap with the EC community by organizing the collection and aggregation of a global $\mathrm{EC} \mathrm{CH}_{4}$ database through FLUXNET.

EC flux data quality assessment. Much of what has been learned within FLUXNET for $\mathrm{CO}_{2}$, water vapor, and energy measurements is informing, and should continue to inform, new efforts for $\mathrm{CH}_{4}$. Reliable EC measurements of $\mathrm{CO}_{2}$ and water vapor fluxes have been conducted at hundreds of sites across broad regional networks (Papale et al. 2012), and substantial efforts have focused on developing best practices and harmonizing approaches across sites to ensure consistent, high-quality flux measurements (Aubinet et al. 1999; Reichstein et al. 2005; Moffat et al. 2007). $\mathrm{CH}_{4}$ fluxes are often characterized by small fluxes with episodic spikes, and additional research is needed to ensure reliable measurements (Peltola et al. 2014, 2013), and refine and standardize methods and routines for data processing and quality checking (Nemitz et al. 2018; Schaller et al. 2018). Recent efforts provided guidance on instrument selection, setup and maintenance, and data processing for $\mathrm{EC} \mathrm{CH}_{4}$ flux measurements (Nemitz et al. 2018). However, with respect to instrument setup and data processing, more research is needed in best practices for storage flux quantification, despiking, and $u_{\star}$ filtering (Nemitz et al. 2018).

Gap-filling. Whereas neural networks have shown strong performance for gap-filling $\mathrm{CH}_{4}$ fluxes (Dengel et al. 2013; Knox et al. 2016), our results reveal some of the challenges of gap-filling $\mathrm{CH}_{4}$ fluxes at sites with low fluxes and/or a lack of seasonal and diel variation (Fig. 8). More research is therefore needed for best practices for gap-filling to estimate annual $\mathrm{CH}_{4}$ budgets (Nemitz et al. 2018). For example, there has yet to be a comprehensive analysis comparing a wide range of gap-filling approaches for $\mathrm{CH}_{4}$ fluxes similar to the study by Moffat et al. (2007) for $\mathrm{CO}_{2}$ exchange. While ANNs are one gap-filling method (Dengel et al. 2013; Shoemaker et al. 2014; Morin et al. 2014a), numerous other gap-filling approaches exist, including nonlinear regression techniques, mean diurnal variation, lookup tables, marginal distribution sampling, and the multiple imputation method (Moffat et al. 2007; Vitale et al. 2019). Future efforts should focus on systematically investigating these approaches across a range of sites to provide best practices for gap-filling $\mathrm{CH}_{4}$ exchange.

Ancillary measurements. Along with research that addresses the challenges of measuring and processing $\mathrm{EC} \mathrm{CH}_{4}$ fluxes, key ancillary variables to help gap-fill, predict, and scale $\mathrm{CH}_{4}$ fluxes should also be measured more comprehensively across sites. For instance, although WTD is known to strongly influence $\mathrm{CH}_{4}$ emissions (Turetsky et al. 2014; Treat et al. 2018b), as noted above, only half of the sites currently included in the database report water table position. Generally, EC $\mathrm{CH}_{4}$ measurements are implemented at sites also collecting $\mathrm{CO}_{2}$ fluxes and common meteorological measurements used in the flux community; however, guidelines are only 
beginning to emerge for which additional supporting variables should be collected at sites measuring $\mathrm{CH}_{4}$ fluxes (Nemitz et al. 2018).

Measurements of variables beyond those relevant for $\mathrm{CO}_{2}$ are needed to better understand and predict the complex and interacting processes of $\mathrm{CH}_{4}$ production, consumption, and transport, the latter of which includes diffusion, ebullition, and plantmediated transport. Guidance on the description of some basic variables affecting these processes is available through new protocols in the flux community detailing soil meteorological measurements, ancillary vegetation measurements, and site description, management and disturbance (Saunders et al. 2018; Op De Beeck et al. 2018; Gielen et al. 2018). These protocols provide guidance on variables such as soil temperature and soil moisture profiles, water table depth and snow depth, soil pH and soil type, bulk density, and livestock density. However, although WTD is an easily measured proxy for anaerobic conditions, direct and continuous measurement of redox potential and oxygen content in particular would be valuable additional measurements (Nemitz et al. 2018). Similarly, measuring variables such as conductivity, below-ground $\mathrm{CH}_{4}$ concentrations, dissolved organic carbon concentrations, and the presence of alternative electron acceptors such as nitrate, iron, sulfate, and humic substances in the water and soil column would provide useful information for the interpretation of $\mathrm{CH}_{4}$ emissions. Stable isotope analyses of $\mathrm{CH}_{4}$ are also valuable as they provide important information on mechanisms of $\mathrm{CH}_{4}$ production, transport, and oxidation (Chanton et al. 1997; Marushchak et al. 2016). Detailed information on soil microbial communities driving $\mathrm{CH}_{4}$ production and consumption could also be helpful (Kwon et al. 2017). Vegetation biomass, species composition, and phenology are also important variables to consider, because plants are a primary source of carbon substrates for methanogenic metabolism, and they mediate $\mathrm{CH}_{4}$ transport through aerenchymous tissue (Kwon et al. 2017; Joabsson et al. 1999; Carmichael et al. 2014). New guidance is now available for such measurements at flux tower locations (Gielen et al. 2018; Hufkens et al. 2018). Continuing to develop a consensus on best practices for ancillary measurements is important for interpreting, gap-filling, and upscaling $\mathrm{CH}_{4}$ flux measurements.

Characterizing spatial variability. $\mathrm{CH}_{4}$ fluxes exhibit finescale spatial variability that can span orders of magnitude within a landscape (Peltola et al. 2015; Marushchak et al. 2016; Desai et al. 2015; Treat et al.

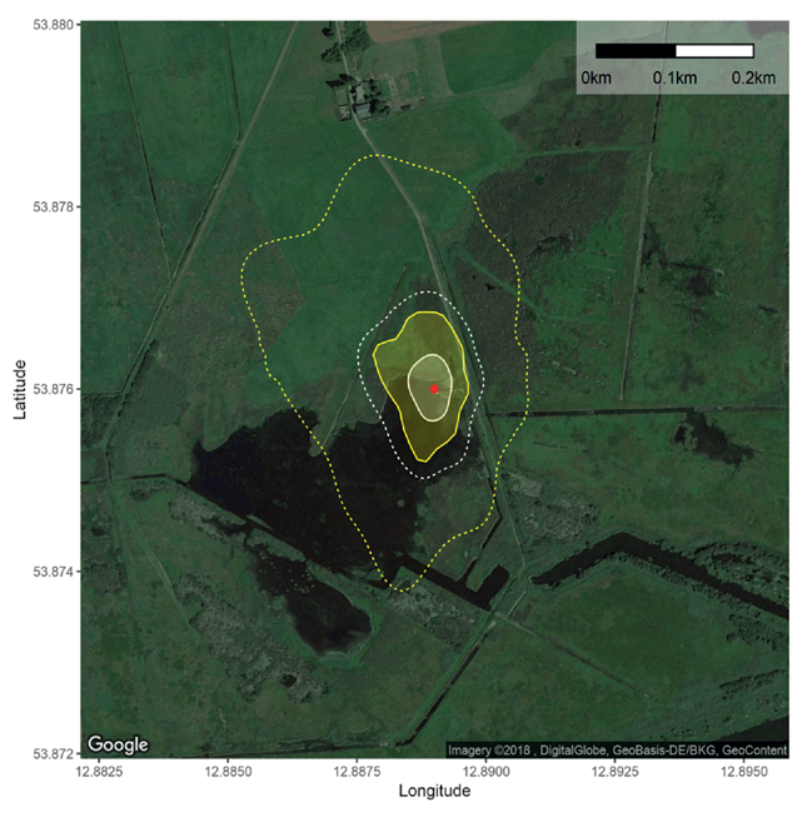

FIG. II. Footprint climatology for a eutrophic shallow lake on a formerly drained fen in Germany (Zarnekow; DE-Zrk) illustrating the importance of footprint analysis for the interpretation of EC measurements of $\mathrm{CH}_{4}$. Here we used two footprint models, including the model of Kormann and Meixner (200I) (yellow) and Kljun et al. (2015) (white). The footprint climatology was calculated by aggregating all half-hour footprints within a year. The dashed lines enclose the areas aggregating to $\mathbf{8 0} \%$ of source areas, while solid lines enclose the $50 \%$ of source areas.

2018a; Iwata et al. 2018), attributable to heterogeneous soil properties and moisture conditions, vegetation composition, and land use (Davidson et al. 2016; Parmentier et al. 2011; Chamberlain et al. 2018). Furthermore, there is evidence that traditionally unmeasured surfaces (i.e., tree stems) are important sources of $\mathrm{CH}_{4}$ to the atmosphere and could explain spatial heterogeneity within ecosystems (Barba et al. 2019). Accurately representing spatial heterogeneity and the relative fraction of uplands and wetlands is imperative for interpreting and predicting $\mathrm{CH}_{4}$ emissions within many ecosystems, and for upscaling flux measurements regionally and globally as wetlands are hot spots for carbon cycling (Treat et al. 2018a; Tuovinen et al. 2019; Rößger et al. 2019). Flux footprint analysis characterizing the fractional coverage of the dominant surface types, particularly the fraction of open water and aerenchymatous plants, is important for interpreting $\mathrm{EC} \mathrm{CH}_{4}$ flux measurements and quantifying annual $\mathrm{CH}_{4}$ budgets at spatially heterogeneous sites (Franz et al. 2016; Helbig et al. 2017a; Jammet et al. 2017) (Fig. 11). This integration can be achieved by combining $\mathrm{CH}_{4}$ measurements, flux footprint analysis, and near-surface 
TABLE AI. The ecosystem type is based on the classification of Olefeldt et al. (2013) and Treat et al. (2018b). Biome was based on the classification of Olson et al. (200I) and extracted using site coordinates. Vegetation type was based on the International Geosphere-Biosphere Programme (IGBP) definition. Salinity regime includes freshwater (FW) or saltwater (SW) wetlands. Disturbance is based on the classification of Turetsky et al. (2014). Data from all sites are publicly available, primarily through AmeriFlux and the European Database Cluster, and in a few cases, through other databases/repositories. Site DOls are specified where applicable.

\begin{tabular}{|c|c|c|c|c|c|c|}
\hline Site ID & Site name & Country & $\begin{array}{l}\text { Lat } \\
\left({ }^{\circ} \mathbf{N}\right)\end{array}$ & $\begin{array}{l}\text { Lon } \\
\left({ }^{\circ} \mathrm{E}\right)\end{array}$ & Biome & IGBP \\
\hline US-ICs & Wet sedge tundra & U.S. & 68.606 & $-\mid 49.311$ & Tundra & WET \\
\hline SE-Stl & Stordalen grassland (mire) & Sweden & 68.350 & 19.050 & Tundra & WET \\
\hline SE-Sto & Stordalen Palsa bog & Sweden & 68.356 & 19.050 & Tundra & WET \\
\hline RU-Vrk & Seida/Vorkuta & Russia & 67.055 & 62.940 & Tundra & WET \\
\hline $\mathrm{RU}-\mathrm{Ch} 2$ & Chersky reference & Russia & 68.617 & 161.351 & Tundra & WET \\
\hline RU-Che & Chersky & Russia & 68.613 & $|6| .34 \mid$ & Tundra & WET \\
\hline RU-SAM & Samoylov & Russia & 72.374 & 126.496 & Tundra & WET \\
\hline US-NGB & NGEE Barrow & U.S. & 71.280 & -156.609 & Tundra & WET \\
\hline US-Beo & Barrow & U.S. & 71.281 & -156.612 & Tundra & WET \\
\hline US-Bes & Barrow & U.S. & 71.281 & -156.596 & Tundra & WET \\
\hline US-Atq & Atqasuk & U.S. & 70.470 & -157.409 & Tundra & WET \\
\hline US-Ivo & Ivotuk & U.S. & 68.486 & -155.750 & Tundra & WET \\
\hline- & Black spruce forest & U.S. & 64.700 & -148.320 & Boreal forests/taiga & ENF \\
\hline- & Rich fen & U.S. & 64.704 & -148.313 & Boreal forests/taiga & WET \\
\hline- & Thermokarst collapse scar bog & U.S. & 64.700 & -148.320 & Boreal forests/taiga & WET \\
\hline FI-Lom & Lompolojankka & Finland & 67.997 & 24.209 & Boreal forests/taiga & WET \\
\hline SE-Deg & Degero & Sweden & 64.182 & 19.557 & Boreal forests/taiga & WET \\
\hline CA-SCC & Scotty Creek-Peat plateau/collapse scar & Canada & 61.308 & -121.299 & Boreal forests/taiga & ENF \\
\hline CA-SCB & Scotty Creek bog & Canada & 61.309 & -121.299 & Boreal forests/taiga & WET \\
\hline US-NGC & NGEE Arctic Council & U.S. & 64.861 & $-163.70 \mid$ & Boreal forests/taiga & WET \\
\hline US-Uaf & University of Alaska Fairbanks & U.S. & 64.866 & -147.856 & Boreal forests/taiga & WET \\
\hline FI-Sii & Siikaneva I (FI-Sii) & Finland & 61.833 & 24.193 & Boreal forests/taiga & WET \\
\hline FI-Si2 & Siikaneva II & Finland & 61.837 & 24.170 & Boreal forests/taiga & WET \\
\hline US-Myb & Mayberry wetland & U.S. & 38.050 & -121.765 & Temperate & WET \\
\hline US-Sne & Sherman Island restored wetland & U.S. & 38.037 & -121.755 & Temperate & WET \\
\hline US-Twl & Twitchell west pond wetland & U.S. & 38.107 & -121.647 & Temperate & WET \\
\hline US-Tw4 & Twitchell east end wetland & U.S. & 38.103 & $-|21.64|$ & Temperate & WET \\
\hline US-Twt & Twitchell rice & U.S. & 38.109 & -121.653 & Temperate & CRO - Rice \\
\hline US-Bi2 & Bouldin Island corn & U.S. & 38.109 & -121.535 & Temperate & CRO - Other \\
\hline US-Bil & Bouldin Island alfalfa & U.S. & 38.102 & -121.504 & Temperate & CRO - Other \\
\hline US-Snd & Sherman Island & U.S. & 38.037 & -121.754 & Temperate & CRO - Other \\
\hline US-OWC & Old Woman Creek & U.S. & 41.380 & -82.512 & Temperate & WET \\
\hline US-Orv & Olentangy River Wetland Research Park & U.S. & 40.020 & -83.018 & Temperate & WET \\
\hline NZ-Kop & Kopuatai & New Zealand & -37.388 & 175.554 & Temperate & WET \\
\hline IT-Cas & Castellaro & Italy & 45.070 & 8.718 & Temperate & CRO - Rice \\
\hline US-WPT & Winous Point north marsh & U.S. & 41.465 & -82.996 & Temperate & WET \\
\hline US-CRT & Curtice Walter-Berger cropland & U.S. & 41.628 & -83.347 & Temperate & CRO - Other \\
\hline US-Los & Lost Creek & U.S. & 46.083 & -89.979 & Temperate & WET \\
\hline JP-Mse & Mase paddy flux site (MSE) & Japan & 36.054 & 140.027 & Temperate & CRO - Rice \\
\hline JP-Swl & Suwa Lake site & Japan & 36.047 & 138.108 & Temperate & WAT \\
\hline IT-BCi & Borgo Cioffi & Italy & 40.524 & 14.957 & Temperate & CRO - Other \\
\hline- & Hongyuan & China & 32.800 & 102.550 & Temperate & GRA \\
\hline US-NC4 & NC Alligator River & U.S. & 35.788 & -75.904 & Temperate & WET \\
\hline DE-SfN & Schechenfilz Nord & Germany & 47.806 & 11.328 & Temperate & WET \\
\hline US-Hol & Howland Forest (main tower) & U.S. & 45.204 & -68.740 & Temperate & ENF \\
\hline US-HRA & Humnoke farm rice field AWD, United States & U.S. & 34.585 & -91.752 & Temperate & CRO - Rice \\
\hline US-HRC & Humnoke farm rice field conventional, United States & U.S. & 34.589 & -91.752 & Temperate & CRO - Rice \\
\hline KR-CRK & Cheorwon rice paddy & South Korea & 38.201 & $127.25 \mid$ & Temperate & CRO - Rice \\
\hline DE-Zrk & Zarnekow & Germany & 53.876 & 12.889 & Temperate & WET \\
\hline DE-Dgw & Dagowsee & Germany & 53.151 & 13.054 & Temperate & WAT \\
\hline US-MRM & Marsh Resource Meadowlands Mitigation Bank & U.S. & 40.816 & -74.044 & Temperate & WET \\
\hline- & Bog Lake peatland & U.S. & 47.530 & -93.470 & Temperate & WET \\
\hline- & MacArthur Agro-Ecology Research Center & U.S. & 27.163 & -81.187 & Temperate & CRO - Other \\
\hline JP-BBY & Bibai bog & Japan & 43.323 & $|4| .8||$ & Temperate & WET \\
\hline US-St] & St. Jones Reserve & U.S. & 39.088 & -75.437 & Temperate & WET \\
\hline US-Srr & Suisun marsh-Rush Ranch & U.S. & 38.201 & -122.026 & Temperate & WET \\
\hline AT-Neu & Neustift & Austria & 47.117 & 11.318 & Temperate & GRA \\
\hline US-LA2 & Salvador WMA freshwater marsh & U.S. & 29.859 & -90.287 & Tropical and subtropical & WET \\
\hline US-LAI & Pointe-aux-Chenes brackish marsh & U.S. & 29.501 & -90.445 & Tropical and subtropical & WET \\
\hline MY-MLM & Maludam & Malaysia & 1.454 & 111.149 & Tropical and subtropical & WET \\
\hline
\end{tabular}




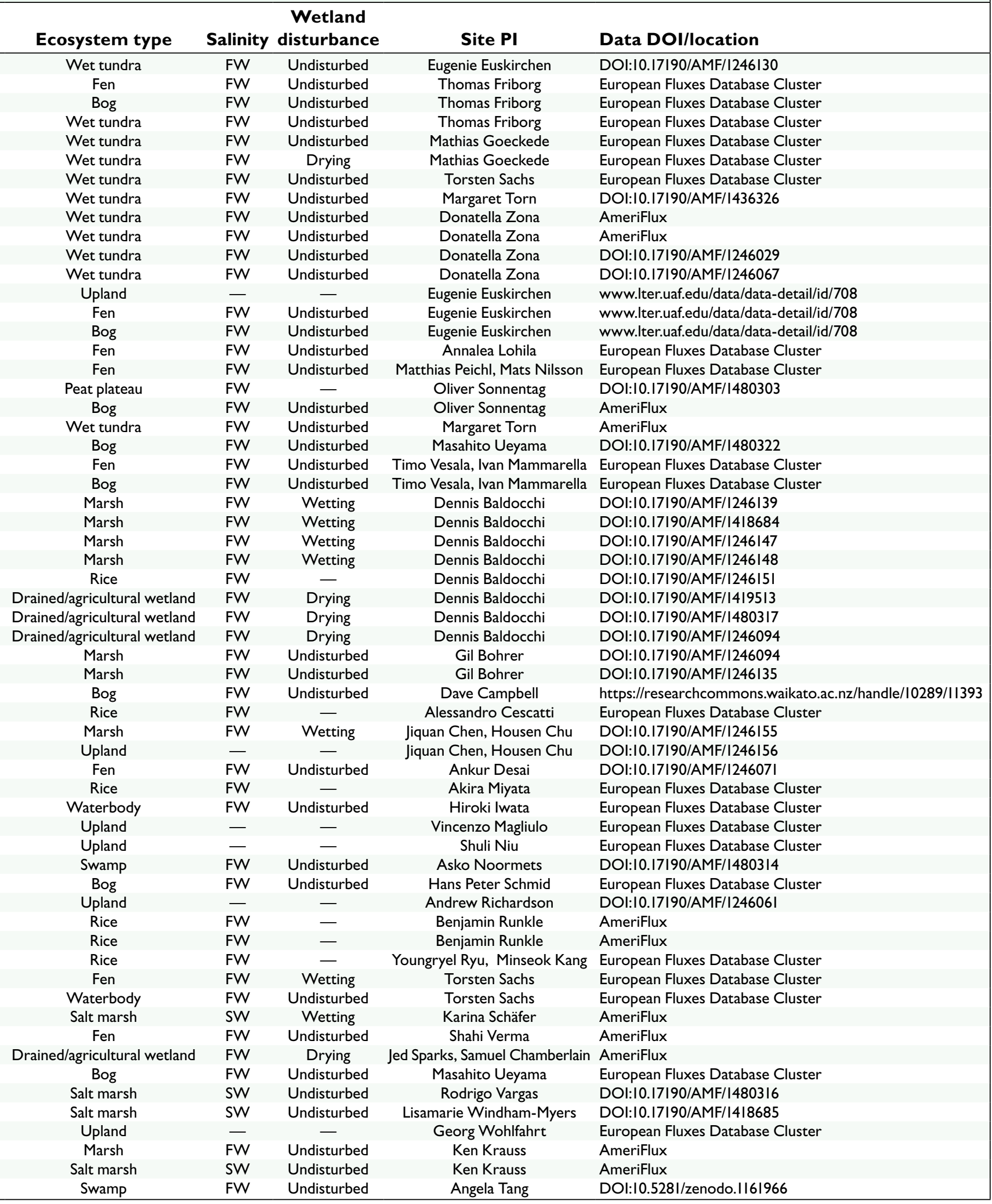


(e.g., phenocams) and/or high-resolution drone or satellite remote sensing data, and should be common practice for all sites measuring $\mathrm{CH}_{4}$ fluxes.

Spatial variability in ecosystem-scale $\mathrm{CH}_{4}$ flux can further be examined by combining chamber and EC measurements, including manual and autochambers, multitower approaches, and airborne flux measurements (Peltola et al. 2015; Zona et al. 2016; Helbig et al. 2017a; Wolfe et al. 2018; Kohnert et al. 2018; Lai et al. 2014; McNicol et al. 2017). Integrating additional observations such as information on microbial communities, isotopic measurements, and laboratory incubation observations along with chamber and $\mathrm{EC} \mathrm{CH}_{4}$ flux measurements can further help explain $\mathrm{CH}_{4}$ dynamics across scales (Angle et al. 2017; Chamberlain et al. 2018; Yang et al. 2017). However, as discussed above, additional research is needed to reconcile differences in fluxes measured across scales (Gioli et al. 2004; Holm et al. 2016; Meijide et al. 2011). Explicitly considering source area composition and spatial heterogeneity will provide enhanced processed-based understanding of $\mathrm{CH}_{4}$ fluxes and improve upscaled regional and global estimates of $\mathrm{CH}_{4}$ emissions, which can help reconcile the discrepancy between bottom-up and top-down budgets (Saunois et al. 2016a; Morin et al. 2017; Davidson et al. 2016).

More sites in key regions. We expect the number of flux towers measuring $\mathrm{CH}_{4}$ fluxes will continue to grow (Chu et al. 2017; Pastorello et al. 2017; Morin 2018), but our compilation of $\mathrm{EC}_{4}$ flux sites highlights key underrepresented regions where future flux towers are needed or where more efforts are needed for existing but nonreporting towers to contribute to FLUXNET (Fig. 1). As noted previously, notable gaps include both tropical and subtropical regions, as well as eastern Canada, and the boreal forests of Russia. Figure 1 also provides guidance on where new towers could be strategically located to help reconcile differences between top-down and bottom-up estimates of wetland $\mathrm{CH}_{4}$ emissions. In particular, substantial disagreements between top-down and bottom-up estimates are found over the Congo basin, the Inner Niger delta, the Orinoco River delta, the Maranon-Ucayali palm swamps, the Pantanal, the Ganges-Brahmaputra delta, Sumatra, the western Siberian lowlands, and the Hudson Bay lowlands (Fig. 1). However, the placement of new towers is a strong function of the scientific question being asked and research funding priorities, and therefore the optimal tower network could be different for different applications (Mahecha et al. 2017; Papale et al. 2015; Villarreal et al. 2018).
Better understanding and representing processes. One of the biggest challenges for understanding ecosystem functioning is resolving overlapping, asynchronous (i.e., lagged) and nonlinear processes (Sturtevant et al. 2016). This challenge is particularly relevant for interpreting continuous, ecosystem-scale measurements of $\mathrm{CH}_{4}$ exchange where scale-specific, nonlinear, and lagged processes may dominate (Franz et al. 2016; Sturtevant et al. 2016; Knox et al. 2018). For instance, $\mathrm{CH}_{4}$ emission responses to water table fluctuation can be nonlinear and lagged on the order of days to months (Goodrich et al. 2015; Sturtevant et al. 2016). $\mathrm{CH}_{4}$ flux has also been observed to lag GPP by hours to days (Rinne et al. 2018; Hatala et al. 2012). Adequately representing these dynamics in process models is important, and further research is needed to better characterize the complex and nonlinear processes influencing ecosystem-scale $\mathrm{CH}_{4}$ exchange across time scales.

The complex nature of $\mathrm{CH}_{4}$ flux dynamics requires moving beyond traditional linear correlation and regression, and using methods such as wavelets, information theory, and Granger causality that are more tailored to address scale, nonlinearity, and lags directly (Stoy et al. 2005; Vargas et al. 2011; Schäfer et al. 2014; Knox et al. 2016; Detto et al. 2012). Through a USGS Powell Center working group activity, we will continue to investigate controls on $\mathrm{CH}_{4}$ emissions within and across wetland types. To further explore interactions between ecosystem-scale $\mathrm{CH}_{4}$ exchange and drivers across time scales, wavelet analysis will be combined with information theory to explore biosphere-atmosphere interactions regardless of form or asynchrony (Sturtevant et al. 2016; Knox et al. 2018; Chamberlain et al. 2018). By coupling wavelet decomposition with information theory, future research will investigate key controls on $\mathrm{CH}_{4}$ fluxes across time scales, as well as the importance of nonlinearities and lags in predicting $\mathrm{CH}_{4}$ flux dynamics. Future research will also use the global $\mathrm{CH}_{4}$ database to parameterize and benchmark the performance of land surface models of global $\mathrm{CH}_{4}$ emissions, providing a unique opportunity for informing and validating biogeochemical models.

Coordinating, organizing and improving the integration of $\mathrm{CH}_{4}$ fluxes in regional networks and ultimately FLUXNET will bring us one step closer to achieving the goal of providing flux information "everywhere and all of the time" (Baldocchi 2008). In the long term, we hope to integrate the global eddy covariance $\mathrm{CH}_{4}$ database with other methods for measuring $\mathrm{CH}_{4}$ fluxes, such as chamber, aircraft, and satellite measurements. By integrating $\mathrm{CH}_{4}$ flux 
measurements, remote sensing, and modeling, we aim to better characterize $\mathrm{CH}_{4}$ emissions from terrestrial ecosystems and ultimately reduce uncertainties in the global $\mathrm{CH}_{4}$ cycle.

ACKNOWLEDGMENTS. This study was supported by the Gordon and Betty Moore Foundation through Grant GBMF5439 "Advancing Understanding of the Global Methane Cycle" to Stanford University supporting the Methane Budget activity for the Global Carbon Project (globalcarbonproject.org). This work was also conducted as a part of the Wetland FLUXNET Synthesis for Methane Working Group supported by the John Wesley Powell Center for Analysis and Synthesis of the U.S. Geological Survey. We acknowledge the following AmeriFlux sites for their data records: CA-SCC, CA-SCB, U.S.-Beo, U.S.-Bes, U.S.-Atq, U.S.-Ivo, U.S.-ICs, U.S.-NGB, U.S.-NGC, U.S.Los, U.S.-NC4, U.S.-HRA, U.S.-HRC, U.S.-Myb, U.S.-Sne, U.S.-Tw1, U.S.-Tw4, U.S.-Twt, U.S.-Bi2, U.S.-Bi1, U.S.-Snd, U.S.-OWC, U.S.-ORv, U.S.-WPT, U.S.-CRT, U.S.-MRM, U.S.-Srr, U.S.-Uaf, U.S.-Ho1, U.S.-StJ, U.S.-LA2, U.S.-LA1. In addition, funding for AmeriFlux data resources were provided by the U.S. Department of Energy's Office of Science. BRKR was supported by NSF Award 1752083. WCO and DZ acknowledge support from NSF 1204263 and 1702797; NASA ABoVE NNX15AT74A, NNX16AF94A, and NNX17AC61A; NOAA EPP NA16SEC4810008; EU Horizon 2020 No. 629 727890; and NERC UK NE/ P002552/1. TFK and HC acknowledge support from the AmeriFlux Management Project. Any use of trade, firm, or product names is for descriptive purposes only and does not imply endorsement by the U.S. government. DP, IM, and TV thank the European Union for supporting the RINGO project funded by the Horizon 2020 Research and Innovation Programme under Grant Agreement 730944. The authors also thank Claire Treat, Nigel Roulet, and another anonymous reviewer for their helpful comments to improve the manuscript.

\section{APPENDIX: SITES CURRENTLY INCLUD-} ED IN THE DATABASE. Table A1 presents characteristics of sites currently included in the database.

\section{REFERENCES}

Anderson, D. E., S. B. Verma, and N. J. Rosenberg, 1984: Eddy correlation measurements of $\mathrm{CO}_{2}$, latent heat, and sensible heat fluxes over a crop surface. Bound.Layer Meteor., 29, 263-272, https://doi.org/10.1007 /BF00119792.

Anderson, F. E., and Coauthors, 2016: Variation of energy and carbon fluxes from a restored temperate freshwater wetland and implications for carbon market verification protocols. J. Geophys. Res. Biogeosci., 121, 777-795, https://doi .org/10.1002/2015JG003083.

Angle, J. C., and Coauthors, 2017: Methanogenesis in oxygenated soils is a substantial fraction of wetland methane emissions. Nat. Commun., 8, 1567, https:// doi.org/10.1038/s41467-017-01753-4.

Arcus, V. L., E. J. Prentice, J. K. Hobbs, A. J. Mulholland, M. W. Van Der Kamp, C. R. Pudney, E. J. Parker, and L. A. Schipper, 2016: On the temperature dependence of enzyme-catalyzed rates. Biochemistry, 55, 16811688, https://doi.org/10.1021/acs.biochem.5b01094.

Aubinet, M., and Coauthors, 1999: Estimates of the annual net carbon and water exchange of forests: The EUROFLUX methodology. Adv. Ecol. Res., 30, 113175, https://doi.org/10.1016/S0065-2504(08)60018-5.

—, T. Vesala, and D. Papale, 2012: Eddy Covariance: $A$ Practical Guide to Measurement and Data Analysis. Springer, $438 \mathrm{pp}$.

Baldocchi, D. D., 2003: Assessing the eddy covariance technique for evaluating carbon dioxide exchange rates of ecosystems: Past, present and future. Global Change Biol., 9, 479-492, https://doi.org/10.1046 /j.1365-2486.2003.00629.x.

_ 2008: 'Breathing' of the terrestrial biosphere: Lessons learned from a global network of carbon dioxide flux measurement systems. Aust. J. Bot., 56, 1-26, https://doi.org/10.1071/BT07151.

_ 2014: Measuring fluxes of trace gases and energy between ecosystems and the atmosphere-The state and future of the eddy covariance method. Global Change Biol., 20, 3600-3609, https://doi.org/10.1111 /gcb.12649.

Barba, J., and Coauthors, 2019: Methane emissions from tree stems: A new frontier in the global carbon cycle. New Phytol., 222, 18-28, https://doi.org/10.1111 /nph.15582.

Bartlett, K. B., and R. C. Harriss, 1993: Review and assessment of methane emissions from wetlands. Chemosphere, 26, 261-320, https://doi.org/10.1016/0045 -6535(93)90427-7.

Bastviken, D., L. J. Tranvik, J. A. Downing, P. M. Crill, and A. Enrich-Prast, 2011: Freshwater methane emissions offset the continental carbon sink. Science, 331, 50, https://doi.org/10.1126/science.1196808.

Bates, D., M. Machler, B. Bolker, and S. Walker, 2015: Fitting linear mixed-effects models using lme4. J. Stat. Software, 67 (1), https://doi.org/10.18637/JSS .V067.I01.

Bousquet, P., and Coauthors, 2006: Contribution of anthropogenic and natural sources to atmospheric methane variability. Nature, 443, 439-443, https:// doi.org/10.1038/nature05132. 
Bridgham, S. D., H. Cadillo-Quiroz, J. K. Keller, and Q. Zhuang, 2013: Methane emissions from wetlands: Biogeochemical, microbial, and modeling perspectives from local to global scales. Global Change Biol., 19, 1325-1346, https://doi.org/10.1111/gcb.12131.

Brix, H., B. K. Sorrell, and P. T. Orr, 1992: Internal pressurization and convective gas flow in some emergent freshwater macrophytes. Limnol. Oceanogr., 37, 1420-1433, https://doi.org/10.4319/lo.1992.37.7.1420.

Bubier, J., T. Moore, K. Savage, and P. Crill, 2005: A comparison of methane flux in a boreal landscape between a dry and a wet year. Global Biogeochem. Cycles, 19, GB1023, https://doi.org/10.1029/2004GB002351.

Carmichael, M. J., E. S. Bernhardt, S. L. Bräuer, and W. K. Smith, 2014: The role of vegetation in methane flux to the atmosphere: Should vegetation be included as a distinct category in the global methane budget? Biogeochemistry, 119, 1-24, https://doi.org /10.1007/s10533-014-9974-1.

Castro-Morales, K., T. Kleinen, S. Kaiser, S. Zaehle, F. Kit-Tler, M. J. Kwon, C. Beer, and M. Göckede, 2018: Year-round simulated methane emissions from a permafrost ecosystem in northeast Siberia. Biogeosciences, 15, 2691-2722, https://doi.org/10.5194 /bg-15-2691-2018.

Cazelles, B., M. Chavez, D. Berteaux, F. Ménard, J. O. Vik, S. Jenouvrier, and N. C. Stenseth, 2008: Wavelet analysis of ecological time series. Oecologia, 156, 287-304, https://doi.org/10.1007/s00442-008-0993-2.

Chamberlain, S. D., and Coauthors, 2018: Soil properties and sediment accretion modulate methane fluxes from restored wetlands. Global Change Biol., 24, 4107-4121, https://doi.org/10.1111/gcb.14124.

Chanton, J. P., G. J. Whiting, J. D. Happell, and G. Gerard, 1993: Contrasting rates and diurnal patterns of methane emission from emergent aquatic macrophytes. Aquat. Bot., 46, 111-128, https://doi.org /10.1016/0304-3770(93)90040-4.

,$- \ldots$, N. E. Blair, C. W. Lindau, and P. K. Bollich, 1997: Methane emission from rice: Stable isotopes, dirunal variations, and $\mathrm{CO}_{2}$ exchange. Global Biogeochem. Cycles, 11, 15-27, https://doi.org/10.1029/96GB03761.

Chen, Y.-H., and R. G. Prinn, 2006: Estimation of atmospheric methane emissions between 1996 and 2001 using a three-dimensional global chemical transport model. J. Geophys. Res., 111, D10307, https://doi.org /10.1029/2005JD006058.

Christensen, T. R., and Coauthors, 2003: Factors controlling large scale variations in methane emissions from wetlands. Geophys. Res. Lett., 30, 1414, https:// doi.org/10.1029/2002GL016848.

Chu, H., J. Chen, J. F. Gottgens, Z. Ouyang, R. John, K. Czajkowski, and R. Becker, 2014: Net ecosystem methane and carbon dioxide exchanges in a Lake Erie coastal marsh and a nearby cropland. J. Geophys. Res. Biogeosci., 119, 722-740, https://doi.org /10.1002/2013JG002520.

- D. D. Baldocchi, R. John, S. Wolf, and M. Reichstein, 2017: Fluxes all of the time? A primer on the temporal representativeness of FLUXNET. J. Geophys. Res. Biogeosci., 122, 289-307, https://doi.org /10.1002/2016JG003576.

Davidson, S. J., V. L. Sloan, G. K. Phoenix, R. Wagner, J. P. Fisher, W. C. Oechel, and D. Zona, 2016: Vegetation type dominates the spatial variability in $\mathrm{CH}_{4}$ emissions across multiple Arctic tundra landscapes. Ecosystems, 19, 1116-1132, https://doi.org/10.1007 /s10021-016-9991-0.

Dean, J. F., and Coauthors, 2018: Methane feedbacks to the global climate system in a warmer world. Rev. Geophys., 56, 207-250, https://doi.org /10.1002/2017RG000559.

Dengel, S., D. Zona, T. Sachs, M. Aurela, M. Jammet, F. J. W. Parmentier, W. Oechel, and T. Vesala, 2013: Testing the applicability of neural networks as a gap-filling method using $\mathrm{CH}_{4}$ flux data from high latitude wetlands. Biogeosciences, 10, 8185-8200, https://doi.org /10.5194/bg-10-8185-2013.

Desai, A. R., and Coauthors, 2015: Landscape-level terrestrial methane flux observed from a very tall tower. Agric. For. Meteor., 201, 61-75, https://doi.org /10.1016/j.agrformet.2014.10.017.

Desjardins, R. L., 1974: A technique to measure $\mathrm{CO}_{2}$ exchange under field conditions. Int. J. Biometeor., 18, 76-83, https://doi.org/10.1007/BF01450667.

Detto, M., A. Molini, G. Katul, P. Stoy, S. Palmroth, and D. Baldocchi, 2012: Causality and persistence in ecological systems: A nonparametric spectral Granger causality approach. Amer. Nat., 179, 524-535, https:// doi.org/10.1086/664628.

Euskirchen, E. S., M. S. Bret-Harte, G. R. Shaver, C. W. Edgar, and V. E. Romanovsky, 2017: Long-term release of carbon dioxide from Arctic tundra ecosystems in Alaska. Ecosystems, 20, 960-974, https:// doi.org/10.1007/S10021-016-0085-9.

Fan, S. M., and Coauthors, 1992: Micrometeorological measurements of $\mathrm{CH}_{4}$ and $\mathrm{CO}_{2}$ exchange between the atmosphere and subarctic tundra. J. Geophys. Res., 97, 16627-16643, https://doi.org/10.1029/91JD02531.

Franz, D., F. Koebsch, E. Larmanou, J. Augustin, and T. Sachs, 2016: High net $\mathrm{CO}_{2}$ and $\mathrm{CH}_{4}$ release at a eutrophic shallow lake on a formerly drained fen. Biogeosciences, 13, 3051-3070, https://doi.org/10.5194 /bg-13-3051-2016.

Gielen, B., and Coauthors, 2018: Ancillary vegetation measurements at ICOS ecosystem stations. Int. 
Agrophys., 10, 645-664, https://doi.org/10.1515 /INTAG-2017-0048.

Gioli, B., and Coauthors, 2004: Comparison between tower and aircraft-based eddy covariance fluxes in five European regions. Agric. For. Meteor., 127, 1-16, https://doi.org/10.1016/j.agrformet.2004.08.004.

Goodrich, J. P., D. I. Campbell, N. T. Roulet, M. J. Clearwater, and L. A. Schipper, 2015: Overriding control of methane flux temporal variability by water table dynamics in a Southern Hemisphere, raised bog. J. Geophys. Res. Biogeosci., 120, 819-831, https://doi .org/10.1002/2014JG002844.

Grant, R. F., and N. T. Roulet, 2002: Methane efflux from boreal wetlands: Theory and testing of the ecosystem model Ecosys with chamber and tower flux measurements. Global Biogeochem. Cycles, 16, 1054, https:// doi.org/10.1029/2001GB001702.

Harris, I., P. D. Jones, T. J. Osborn, and D. H. Lister, 2014: Updated high-resolution grids of monthly climatic observations-The CRU TS3.10 dataset. Int. J. Climatol., 34, 623-642, https://doi.org/10.1002/joc.3711.

Hatala, J. A., M. Detto, and D. D. Baldocchi, 2012: Gross ecosystem photosynthesis causes a diurnal pattern in methane emission from rice. Geophys. Res. Lett., 39, L06409, https://doi.org/10.1029/2012GL051303.

Helbig, M., L. E. Chasmer, N. C. Kljun, W. L. Quinton, C. C. Treat, and O. Sonnentag, 2017a: The positive net radiative greenhouse gas forcing of increasing methane emissions from a thawing boreal forest-wetland landscape. Global Change Biol., 23, 2413-2427, https://doi.org/10.1111/gcb.13520.

—, W. L. Quinton, and O. Sonnentag, 2017b: Warmer spring conditions increase annual methane emissions from a boreal peat landscape with sporadic permafrost. Environ. Res. Lett., 12, 115009, https:// doi.org/10.1088/1748-9326/aa8c85.

Hendriks, D. M. D., J. van Huissteden, and A. J. Dolman, 2010: Multi-technique assessment of spatial and temporal variability of methane fluxes in a peat meadow. Agric. For. Meteor., 150, 757-774, https:// doi.org/10.1016/j.agrformet.2009.06.017.

Hollinger, A. D., and A. D. Richardson, 2005: Uncertainty in eddy covariance measurements and its application to physiological models. Tree Physiol., 25, 873-885, https://doi.org/10.1093/treephys /25.7.873.

Holm, G. O., B. C. Perez, D. E. McWhorter, K. W. Krauss, D. J. Johnson, R. C. Raynie, and C. J. Killebrew, 2016: Ecosystem level methane fluxes from tidal freshwater and brackish marshes of the Mississippi River delta: Implications for coastal wetland carbon projects. Wetlands, 36, 401-413, https://doi.org/10.1007 /s13157-016-0746-7.
Hufkens, K., and Coauthors, 2018: Assimilating phenology datasets automatically across ICOS ecosystem stations. Int. Agrophys., 32, 677-687, https://doi .org/10.1515/intag-2017-0050.

Iwata, H., R. Hirata, Y. Takahashi, Y. Miyabara, M. Itoh, and K. Iizuka, 2018: Partitioning eddy-covariance methane fluxes from a shallow lake into diffusive and ebullitive fluxes. Bound.-Layer Meteor., 169, 413-428, https://doi.org/10.1007/s10546-018-0383-1.

Jackowicz-Korczyński, M., T. R. Christensen, K. Bäckstrand, P. Crill, T. Friborg, M. Mastepanov, and L. Ström, 2010: Annual cycle of methane emission from a subarctic peatland. J. Geophys. Res, 115, G02009, https://doi.org/10.1029/2008JG000913.

Jammet, M., S. Dengel, E. Kettner, F.-J. W. Parmentier, M. Wik, P. Crill, and T. Friborg, 2017: Year-round $\mathrm{CH}_{4}$ and $\mathrm{CO}_{2}$ flux dynamics in two contrasting freshwater ecosystems of the subarctic. Biogeosciences, 14, 5189-5216, https://doi.org/10.5194/bg-14-5189-2017.

Joabsson, A., T. R. Christensen, and B. Wallén, 1999: Vascular plant controls on methane emissions from northern peatforming wetlands. Trends Ecol. Evol., 14, 385-388, https://doi.org/10.1016/S0169 -5347(99)01649-3.

Jung, M., M. Reichstein, and A. Bondeau, 2009: Towards global empirical upscaling of FLUXNET eddy covariance observations: Validation of a model tree ensemble approach using a biosphere model. Biogeosciences, 6, 2001-2013, https://doi.org/10.5194 /BG-6-2001-2009.

Kim, J., S. B. Verma, and D. P. Billesbach, 1999: Seasonal variation in methane emission from a temperate Phragmites-dominated marsh: Effect of growth stage and plant-mediated transport. Global Change Biol., 5, 433-440, https://doi.org/10.1046/j.1365 -2486.1999.00237.x.

Kittler, F., M. Heimann, O. Kolle, N. Zimov, S. Zimov, and M. Göckede, 2017: Long-term drainage reduces $\mathrm{CO}_{2}$ uptake and $\mathrm{CH}_{4}$ emissions in a Siberian permafrost ecosystem. Global Biogeochem. Cycles, 31, 1704-1717, https://doi.org/10.1002/2017GB005774.

Kljun, N., P. Calanca, M. W. Rotach, and H. P. Schmid, 2015: A simple two-dimensional parameterisation for flux footprint prediction (FFP). Geosci. Model Dev., 8, 3695-3713, https://doi.org/10.5194/gmd-8-3695-2015.

Knox, S. H., C. Sturtevant, J. H. Matthes, L. Koteen, J. Verfaillie, and D. Baldocchi, 2015: Agricultural peatland restoration: Effects of land-use change on greenhouse gas $\left(\mathrm{CO}_{2}\right.$ and $\left.\mathrm{CH}_{4}\right)$ fluxes in the Sacramento-San Joaquin delta. Global Change Biol., 21, 750-765, https://doi.org/10.1111/gcb.12745.

— J. J. Matthes, C. Sturtevant, P. Y. Oikawa, J. Verfaillie, and D. Baldocchi, 2016: Biophysical 
controls on interannual variability in ecosystem-scale $\mathrm{CO}_{2}$ and $\mathrm{CH}_{4}$ exchange in a California rice paddy. $J$. Geophys. Res. Biogeosci., 121, 978-1001, https://doi.org /10.1002/2015JG003247.

—, L. Windham-Myers, F. Anderson, C. Sturtevant, and B. Bergamaschi, 2018: Direct and indirect effects of tides on ecosystem-scale $\mathrm{CO}_{2}$ exchange in a brackish tidal marsh in Northern California. $J$. Geophys. Res. Biogeosci., 123, 787-806, https://doi .org/10.1002/2017JG004048.

Koebsch, F., G. Jurasinski, M. Koch, J. Hofmann, and S. Glatzel, 2015: Controls for multi-scale temporal variation in ecosystem methane exchange during the growing season of a permanently inundated fen. Agric. For. Meteor., 204, 94-105, https://doi .org/10.1016/j.agrformet.2015.02.002.

Kohnert, K., B. Juhls, S. Muster, S. Antonova, A. Serafimovich, S. Metzger, J. Hartmann, and T. Sachs, 2018: Toward understanding the contribution of waterbodies to the methane emissions of a permafrost landscape on a regional scale-A case study from the Mackenzie delta, Canada. Global Change Biol., 24, 3976-3989, https://doi.org/10.1111/gcb.14289.

Kormann, R., and F. X. Meixner, 2001: An analytical footprint model for non-neutral stratification. Bound.-Layer Meteor., 99, 207-224, https://doi.org /10.1023/A:1018991015119.

Krauss, K. W., and Coauthors, 2016: Component greenhouse gas fluxes and radiative balance from two deltaic marshes in Louisiana: Pairing chamber techniques and eddy covariance. J. Geophys. Res. Biogeosci., 121, 1503-1521, https://doi.org/10.1002/2015JG003224.

Kwon, M. J., and Coauthors, 2017: Plants, microorganisms, and soil temperatures contribute to a decrease in methane fluxes on a drained Arctic floodplain. Global Change Biol., 23, 2396-2412, https://doi.org /10.1111/gcb.13558.

Lai, D. Y. F., T. R. Moore, and N. T. Roulet, 2014: Spatial and temporal variations of methane flux measured by autochambers in a temperate ombrotrophic peatland. J. Geophys. Res. Biogeosci., 119, 864-880, https://doi.org/10.1002/2013JG002410.

Lasslop, G., M. Reichsten, D. Papale, A. D. R. Iichardson, A. Arneth, A. Barr, P. Stoy, and G. Wohlfahrt, 2010: Separation of net ecosystem exchange into assimilation and respiration using a light response curve approach: Critical issues and global evaluation. Global Change Biol., 16, 187-208, https://doi.org /10.1111/j.1365-2486.2009.02041.x.

Lehner, B., and P. Döll, 2004: Development and validation of a global database of lakes, reservoirs and wetlands. J. Hydrol., 296, 1-22, https://doi.org/10.1016/j .jhydrol.2004.03.028.
Mahecha, M. D., and Coauthors, 2017: Detecting impacts of extreme events with ecological in situ monitoring networks. Biogeosciences, 14, 4255-4277, https://doi.org/10.5194/bg-14-4255-2017.

Marushchak, M. E., and Coauthors, 2016: Methane dynamics in the subarctic tundra: Combining stable isotope analyses, plot- and ecosystem-scale flux measurements. Biogeosciences, 13, 597-608, https:// doi.org/10.5194/bg-13-597-2016.

MathWorks, 2018: MATLAB, version 9.5. MathWorks.

McDermitt, D., and Coauthors, 2011: A new low-power, open-path instrument for measuring methane flux by eddy covariance. Appl. Phys., 102B, 391-405, https://doi.org/10.1007/s00340-010-4307-0.

McNicol, G., C. S. Sturtevant, S. H. Knox, I. Dronova, D. D. Baldocchi, and W. L. Silver, 2017: Effects of seasonality, transport pathway, and spatial structure on greenhouse gas fluxes in a restored wetland. Global Change Biol., 23, 2768-2782, https://doi.org/10.1111 /GCB.13580.

McNorton, J., and Coauthors, 2016: Role of regional wetland emissions in atmospheric methane variability. Geophys. Res. Lett., 43, 11 433-11444, https:// doi.org/10.1002/2016GL070649.

Meijide, A., G. Manca, I. Goded, V. Magliulo, P. di Tommasi, G. Seufert, and A. Cescatti, 2011: Seasonal trends and environmental controls of methane emissions in a rice paddy field in northern Italy. Biogeosciences, 8, 3809-3821, https://doi.org/10.5194 /bg-8-3809-2011.

Melton, J. R., and Coauthors, 2013: Present state of global wetland extent and wetland methane modelling: Conclusions from a model inter-comparison project (WETCHIMP). Biogeosciences, 10, 753-788, https:// doi.org/10.5194/bg-10-753-2013.

Mitsch, W. J., A. Nahlik, P. Wolski, B. Bernal, L. Zhang, and L. Ramberg, 2009: Tropical wetlands: Seasonal hydrologic pulsing, carbon sequestration, and methane emissions. Wetlands Ecol. Manage., 18, 573-586, https://doi.org/10.1007/S11273-009-9164-4.

Moffat, A. M., and Coauthors, 2007: Comprehensive comparison of gap-filling techniques for eddy covariance net carbon fluxes. Agric. For. Meteor., 147, 209232, https://doi.org/10.1016/j.agrformet.2007.08.011.

Morin, T. H., 2018: Advances in the eddy covariance approach to $\mathrm{CH}_{4}$ monitoring over two and a half decades. J. Geophys. Res. Biogeosci., 124, 453-460, https://doi.org/10.1029/2018JG004796.

—, G. Bohrer, R. P. M. Frasson, L. Naor-Azreli, S. Mesi, K. C. Stefanik, and K. V. R. Schäfer, 2014a: Environmental drivers of methane fluxes from an urban temperate wetland park. J. Geophys. Res. Biogeosci., 119, 2188-2208, https://doi.org/10.1002/2014JG002750. 
,-- L. Naor-Azrieli, S. Mesi, W. T. Kenny, W. J. Mitsch, and K. V. R. Schäfer, 2014b: The seasonal and diurnal dynamics of methane flux at a created urban wetland. Ecol. Eng., 72, 74-83, https://doi .org/10.1016/j.ecoleng.2014.02.002.

,,-- K. C. Stefanik, A. C. Rey-Sanchez, A. M. Matheny, and W. J. Mitsch, 2017: Combining eddycovariance and chamber measurements to determine the methane budget from a small, heterogeneous urban floodplain wetland park. Agric. For. Meteor., 237-238, 160-170, https://doi.org/10.1016/j .agrformet.2017.01.022.

Myhre, G., and Coauthors, 2013: Anthropogenic and natural radiative forcing. Climate Change 2013: The Physical Science Basis, T. F. Stocker et al., Eds., Cambridge University Press, 659-740.

Nadeau, D. F., A. N. Rousseau, C. Coursolle, H. A. Margolis, and M. B. Parlange, 2013: Summer methane fluxes from a boreal bog in northern Quebec, Canada, using eddy covariance measurements. Atmos. Environ., 81, 464-474, https://doi.org/10.1016/J .ATMOSENV.2013.09.044.

Nakagawa, S., and H. Schielzeth, 2013: A general and simple method for obtaining $R 2$ from generalized linear mixed-effects models. Methods Ecol. Evol., 4, 133-142, https://doi.org/10.1111/j.2041-210x.2012.00261.x.

Nemitz, E., and Coauthors, 2018: Standardisation of eddy-covariance flux measurements of methane and nitrous oxide. Int. Agrophys., 32, 517-549, https://doi .org/10.1515/intag-2017-0042.

Oikawa, P. Y., and Coauthors, 2017: Evaluation of a hierarchy of models reveals importance of substrate limitation for predicting carbon dioxide and methane exchange in restored wetlands. $J$. Geophys. Res. Biogeosci., 122, 145-167, https://doi .org/10.1002/2016JG003438.

Olefeldt, D., M. R. Turetsky, P. M. Crill, and A. D. McGuire, 2013: Environmental and physical controls on northern terrestrial methane emissions across permafrost zones. Global Change Biol., 19, 589-603, https://doi.org/10.1111/gcb.12071.

Olson, D. M., and Coauthors, 2001: Terrestrial ecoregions of the world: A new map of life on Earth. BioScience, 51, 933-938, https://doi.org/10.1641/0006 -3568(2001)051[0933:TEOTWA]2.0.CO;2.

Op De Beeck, M., and Coauthors, 2018: Soil-meteorological measurements at ICOS monitoring stations in terrestrial ecosystems. Int. Agrophys., 32, 619-631, https://doi.org/10.1515/intag-2017-0041.

Pangala, S. R., and Coauthors, 2017: Large emissions from floodplain trees close the Amazon methane budget. Nature, 552, 230-234, https://doi.org /10.1038/nature24639.
Papale, D., D. Agarwal, D. Baldocchi, R. Cook, J. B. Fisher, and C. van Ingen, 2012: Database maintenance, data sharing policy, collaboration. Eddy Covariance: A Practical Guide to Measurement and Data Analysis, M. Aubinet, T. Vesala, and D. Papale, Eds., Springer, 399-424.

_ - and Coauthors, 2015: Effect of spatial sampling from European flux towers for estimating carbon and water fluxes with artificial neural networks. $J$. Geophys. Res. Biogeosci., 120, 1941-1957, https://doi .org/10.1002/2015JG002997.

Parmentier, F. J. W., J. Van Huissteden, M. K. Van Der Molen, G. Schaepman-Strub, S. A. Karsanaev, T. C. Maximov, and A. J. Dolman, 2011: Spatial and temporal dynamics in eddy covariance observations of methane fluxes at a tundra site in northeastern Siberia. J. Geophys. Res., 116, G03016, https://doi.org /10.1029/2010JG001637.

Pastorello, G. Z., D. Papale, H. Chu, C. Trotta, D. Agarwal, E. Canfora, D. Baldocchi, and M. Torn, 2017: A new data set to keep a sharper eye on landair exchanges. Eos, Trans. Amer. Geophys. Union, 98, https://doi.org/10.1029/2017EO071597.

Peltola, O., I. Mammarella, S. Haapanala, G. Burba, and T. Vesala, 2013: Field intercomparison of four methane gas analyzers suitable for eddy covariance flux measurements. Biogeosciences, 10, 3749-3765, https://doi.org/10.5194/bg-10-3749-2013.

— , and Coauthors, 2014: Evaluating the performance of commonly used gas analysers for methane eddy covariance flux measurements: The InGOS inter-comparison field experiment. Biogeosciences, 11, 3163-3186, https://doi.org/10.5194/bg-11 -3163-2014.

_- and Coauthors, 2015: Studying the spatial variability of methane flux with five eddy covariance towers of varying height. Agric. For. Meteor., 214-215, 456-472, https://doi.org/10.1016/j.agrformet.2015.09.007.

—, and Coauthors, 2019: Monthly gridded data product of northern wetland methane emissions based on upscaling eddy covariance observations. Earth Syst. Sci. Data, 11, 1263-1289, https://doi.org/10.5194 lessd-11-1263-2019.

Petrescu, A. M. R., and Coauthors, 2015: The uncertain climate footprint of wetlands under human pressure. Proc. Natl. Acad. Sci. USA, 112, 4594-4599, https:// doi.org/10.1073/pnas.1416267112.

Poffenbarger, H., B. Needelman, and J. P. Megonigal, 2011: Salinity influence on methane emissions from tidal marshes. Wetlands, 31, 831-842, https://doi.org /10.1007/s13157-011-0197-0.

Poulter, B., and Coauthors, 2017: Global wetland contribution to 2000-2012 atmospheric methane growth 
rate dynamics. Environ. Res. Lett., 12, 094013, https:// doi.org/10.1088/1748-9326/aa8391.

Pugh, C. A., D. E. Reed, A. R. Desai, and B. N. Sulman, 2018: Wetland flux controls: How does interacting water table levels and temperature influence carbon dioxide and methane fluxes in northern Wisconsin? Biogeochemistry, 137, 15-25, https://doi.org/10.1007 /s10533-017-0414-x.

R Core Team, 2018: R: A language and environment for statistical computing. R Foundation for Statistical Computing, www.R-project.org/.

Reichstein, M., and Coauthors, 2005: On the separation of net ecosystem exchange into assimilation and ecosystem respiration: Review and improved algorithm. Global Change Biol., 11, 1424-1439, https:// doi.org/10.1111/j.1365-2486.2005.001002.x.

Rey-Sanchez, A. C., T. H. Morin, K. C. Stefanik, K. Wrighton, and G. Bohrer, 2018: Determining total emissions and environmental drivers of methane flux in a Lake Erie estuarine marsh. Ecol. Eng., 114, 7-15, https://doi.org/10.1016/j.ecoleng.2017 .06 .042 .

Richardson, A. D., and D. Y. Hollinger, 2007: A method to estimate the additional uncertainty in gap-filled NEE resulting from long gaps in the $\mathrm{CO}_{2}$ flux record. Agric. For. Meteor., 147, 199-208, https://doi.org /10.1016/j.agrformet.2007.06.004.

— , and Coauthors, 2006: A multi-site analysis of random error in tower-based measurements of carbon and energy fluxes. Agric. For. Meteor., 136, 1-18, https://doi.org/10.1016/j.agrformet.2006.01.007.

_, and Coauthors, 2008: Statistical properties of random $\mathrm{CO}_{2}$ flux measurement uncertainty inferred from model residuals. Agric. For. Meteor., 148, 38-50, https://doi.org/10.1016/j.agrformet.2007.09.001.

—, M. Aubinet, A. G. Barr, D. Y. Hollinger, A. Ibrom, G. Lasslop, and M. Reichstein, 2012: Uncertainty quantification. Eddy Covariance: A Practical Guide to Measurement and Data Analysis, M. Aubinet, T. Vesala, and D. Papale, Eds., Springer, 173-209.

Riley, W. J., Z. M. Subin, D. M. Lawrence, S. C. Swenson, M. S. Torn, L. Meng, N. M. Mahowald, and P. Hess, 2011: Barriers to predicting changes in global terrestrial methane fluxes: Analyses using CLM4Me, a methane biogeochemistry model integrated in CESM. Biogeosciences, 8, 1925-1953, https://doi.org /10.5194/bg-8-1925-2011.

Rinne, J., T. Riutta, M. Pihlatie, M. Aurela, S. Haapanala, J.-P. Tuovinen, E.-S. Tuittila, and T. Vesala, 2007: Annual cycle of methane emission from a boreal fen measured by the eddy covariance technique. Tellus, 59B, 449-457, https://doi.org/10.1111/j.1600 -0889.2007.00261.x.
— ecosystem scale methane emission from a boreal fen in relation to temperature, water table position, and carbon dioxide fluxes. Global Biogeochem. Cycles, 32, 1087-1106, https://doi.org/10.1029 /2017GB005747.

Rößger, N., C. Wille, G. Veh, J. Boike, and L. Kutzbach, 2019: Scaling and balancing methane fluxes in a heterogeneous tundra ecosystem of the Lena River delta. Agric. For. Meteor., 266-267, 243-255, https:// doi.org/10.1016/j.agrformet.2018.06.026.

Runkle, B. R. K., K. Suvoč, M. L. Reba, C. W. Reavis, S. F. Smith, Y.-L. Chiu, and B. Fong, 2019: Methane emission reductions from the alternate wetting and drying of rice fields detected using the eddy covariance method. Environ. Sci. Technol., 53, 671-681, https://doi.org/10.1021/acs.est.8b05535.

Sachs, T., C. Wille, J. Boike, and L. Kutzbach, 2008: Environmental controls on ecosystem-scale $\mathrm{CH}_{4}$ emission from polygonal tundra in the Lena River delta, Siberia. J. Geophys. Res, 113, G00A03, https:// doi.org/10.1029/2007JG000505.

Sass, R., 2003: $\mathrm{CH}_{4}$ emissions from rice agriculture. Good practice guidance and uncertainty management in national greenhouse gas inventories, IPCC Rep., 399-417.

Saunders, M., and Coauthors, 2018: Importance of reporting ancillary site characteristics, and management and disturbance information at ICOS stations. Int. Agrophys., 32, 457-469, https://doi.org/10.1515 /intag-2017-0040.

Saunois, M., and Coauthors, 2016a: The global methane budget 2000-2012. Earth Syst. Sci. Data, 8, 697-751, https://doi.org/10.5194/essd-8-697-2016.

- R. B. Jackson, P. Bousquet, B. Poulter, and J. G. Canadell, 2016b: The growing role of methane in anthropogenic climate change. Environ. Res. Lett., 11, 120207, https://doi.org/10.1088/1748-9326/11 /12/120207.

— - and Coauthors, 2017: Variability and quasi-decadal changes in the methane budget over the period 20002012. Atmos. Chem. Phys., 17, 11 135-11 161, https:// doi.org/10.5194/acp-17-11135-2017.

Schäfer, K. V. R., R. Tripathee, F. Artigas, T. H. Morin, and G. Bohrer, 2014: Carbon dioxide fluxes of an urban tidal marsh in the Hudson-Raritan estuary. J. Geophys. Res. Biogeosci., 119, 2065-2081, https://doi. org/10.1002/2014JG002703.

Schaller, C., F. Kittler, T. Foken, and M. Göckede, 2018: Characterisation of short-term extreme methane fluxes related to non-turbulent mixing above an Arctic permafrost ecosystem. Atmos. Chem. Phys., 19, 4041-4059, https://doi.org/10.5194/acp-19-4041-2019. 
Schipper, L. A., J. K. Hobbs, S. Rutledge, and V. L. Arcus, 2014: Thermodynamic theory explains the temperature optima of soil microbial processes and high Q10 values at low temperatures. Global Change Biol., 20, 3578-3586, https://doi.org/10.1111/gcb.12596.

Schrier-Uijl, A. P., P. S. Kroon, A. Hensen, P. A. Leffelaar, F. Berendse, and E. M. Veenendaal, 2010: Comparison of chamber and eddy covariance-based $\mathrm{CO}_{2}$ and $\mathrm{CH}_{4}$ emission estimates in a heterogeneous grass ecosystem on peat. Agric. For. Meteor., 150, 825-831, https://doi.org/10.1016/J.AGRFORMET.2009.11.007.

Shoemaker, J. K., T. F. Keenan, D. Y. Hollinger, and A. D. Richardson, 2014: Forest ecosystem changes from annual methane source to sink depending on late summer water balance. Geophys. Res. Lett., 41, 673-679, https://doi.org/10.1002/2013GL058691.

Shurpali, N. J., and S. B. Verma, 1998: Micrometeorological measurements of methane flux in a Minnesota peatland during two growing seasons. Biogeochemistry, 40, 1-15, https://doi.org /10.1023/A:1005875307146.

Stoy, P. C., G. G. Katul, M. B. S. Siqueira, J.-Y. Juang, H. R. McCarthy, H.-S. Kim, A. C. Oishi, and R. Oren, 2005: Variability in net ecosystem exchange from hourly to inter-annual time scales at adjacent pine and hardwood forests: A wavelet analysis. Tree Physiol., 25, 887-902, https://doi.org/10.1093 /treephys/25.7.887.

Sturtevant, C., B. L. Ruddell, S. H. Knox, J. Verfaillie, J. H. Matthes, P. Y. Oikawa, and D. Baldocchi, 2016: Identifying scale-emergent, nonlinear, asynchronous processes of wetland methane exchange. J. Geophys. Res. Biogeosci., 121, 188-204, https://doi .org/10.1002/2015JG003054.

Torrence, C., and G. P. Compo, 1998: A practical guide to wavelet analysis. Bull. Amer. Meteor. Soc., 79, 61-78, https://doi.org/10.1175/1520-0477 (1998)079<0061:APGTWA>2.0.CO;2.

Tramontana, G., and Coauthors, 2016: Predicting carbon dioxide and energy fluxes across global FLUXNET sites with regression algorithms. Biogeosciences, 13, 4291-4313, https://doi.org/10.5194 /bg-13-4291-2016.

Treat, C. C., J. L. Bubier, R. K. Varner, and P. M. Crill, 2007: Timescale dependence of environmental and plant-mediated controls on $\mathrm{CH}_{4}$ flux in a temperate fen. J. Geophys. Res., 112, G01014, https://doi.org /10.1029/2006JG000210.

— , and Coauthors, 2018a: Tundra landscape heterogeneity, not interannual variability, controls the decadal regional carbon balance in the western Russian Arctic. Global Change Biol., 24, 5188-5204, https://doi.org/10.1111/gcb.14421.
—, A. A. Bloom, and M. E. Marushchak, 2018b: Nongrowing season methane emissions-A significant component of annual emissions across northern ecosystems. Global Change Biol., 24, 3331-3343, https://doi.org/10.1111/gcb.14137.

Tuovinen, J.-P., and Coauthors, 2019: Interpreting eddy covariance data from heterogeneous Siberian tundra: Land-cover-specific methane fluxes and spatial representativeness. Biogeosciences, 16, 255-274, https:// doi.org/10.5194/bg-16-255-2019.

Turetsky, M. R., and Coauthors, 2014: A synthesis of methane emissions from 71 northern, temperate, and subtropical wetlands. Global Change Biol., 20, 2183-2197, https://doi.org/10.1111/gcb.12580.

Turner, A. J., C. Frankenberg, and E. A. Kort, 2019: Interpreting contemporary trends in atmospheric methane. Proc. Natl. Acad. Sci. USA, 116, 2805-2813, https://doi.org/10.1073/pnas.1814297116.

Vargas, R., D. D. Baldocchi, M. Bahn, P. J. Hanson, K. P. Hosman, L. Kulmala, J. Pumpanen, and B. Yang, 2011: On the multi-temporal correlation between photosynthesis and soil $\mathrm{CO}_{2}$ efflux: Reconciling lags and observations. New Phytol., 191, 1006-1017, https://doi.org/10.1111/j.1469-8137.2011.03771.x.

Verma, S. B., F. G. Ullman, D. Billesbach, R. J. Clement, J. Kim, and E. S. Verry, 1992: Eddy correlation measurements of methane flux in a northern peatland ecosystem. Bound.-Layer Meteor., 58, 289-304, https://doi.org/10.1007/BF02033829.

Villarreal, S., M. Guevara, D. Alcaraz-Segura, N. A. Brunsell, D. Hayes, H. W. Loescher, and R. Vargas, 2018: Ecosystem functional diversity and the representativeness of environmental networks across the conterminous United States. Agric. For. Meteor., 262, 423433, https://doi.org/10.1016/j.agrformet.2018.07.016.

Vitale, D., M. Bilancia, and D. Papale, 2019: A multiple imputation strategy for eddy covariance data. J. Environ. Inform., 34, 68-87, https://doi.org/10.3808 /jei.201800391.

Vuichard, N., and D. Papale, 2015: Filling the gaps in meteorological continuous data measured at FLUXNET sites with ERA-Interim reanalysis. Earth Syst. Sci. Data, 7, 157-171, https://doi.org/10.5194/essd-7-157-2015.

Wahlen, M., 1993: The global methane cycle. Annu. Rev. Earth Planet. Sci., 21, 407-426, https://doi. org/10.1146/annurev.ea.21.050193.002203.

Windham-Myers, L., B. Bergamaschi, F. Anderson, S. Knox, R. Miller, and R. Fujii, 2018: Potential for negative emissions of greenhouse gases $\left(\mathrm{CO}_{2}, \mathrm{CH}_{4}\right.$ and $\mathrm{N}_{2} \mathrm{O}$ ) through coastal peatland re-establishment: Novel insights from high frequency flux data at meter and kilometer scales. Environ. Res. Lett., 13, 045005, https://doi.org/10.1088/1748-9326/aaae74. 
Wolfe, G. M., and Coauthors, 2018: The NASA Carbon Airborne Flux Experiment (CARAFE): Instrumentation and methodology. Atmos. Meas. Tech., 11, 1757-1776, https://doi.org/10.5194/amt-11-1757-2018.

Wutzler, T., A. Lucas-Moffat, M. Migliavacca, J. Knauer, K. Sickel, L. Šigut, O. Menzer, and M. Reichstein, 2018: Basic and extensible post-processing of eddy covariance flux data with REddyProc. Biogeosciences, 15, 5015-5030, https://doi.org/10.5194/bg-15 $-5015-2018$.

Xu, K., S. Metzger, and A. R. Desai, 2017: Upscaling tower-observed turbulent exchange at fine spatiotemporal resolution using environmental response functions. Agric. For. Meteor., 232, 10-22, https:// doi.org/10.1016/j.agrformet.2016.07.019.

Yagi, K., and K. Minami, 1990: Effect of organic matter application on methane emission from some Japanese paddy fields. Soil Sci. Plant Nutr., 36, 599-610, https://doi.org/10.1080/00380768.1990.10416797.
Yang, W. H., G. McNicol, Y. A. Teh, K. Estera-Molina, T. E. Wood, and W. L. Silver, 2017: Evaluating the classical versus an emerging conceptual model of peatland methane dynamics. Global Biogeochem. Cycles, 31, 1435-1453, https://doi.org/10.1002/2017GB005622.

Yvon-Durocher, G., A. P. Allen, D. Bastviken, R. Conrad, C. Gudasz, A. St-Pierre, N. Thanh-Duc, and P. A. del Giorgio, 2014: Methane fluxes show consistent temperature dependence across microbial to ecosystem scales. Nature, 507, 488-491, https://doi.org/10.1038 /nature13164.

Zona, D., and Coauthors, 2016: Cold season emissions dominate the Arctic tundra methane budget. Proc. Natl. Acad. Sci. USA, 113, 40-45, https://doi .org/10.1073/pnas.1516017113.

Zuur, A. F., E. N. Ieno, N. J. Walker, A. A. Saveliev, and G. M. Smith, 2009: Mixed effects modelling for nested data. Mixed Effects Models and Extensions in Ecology with R, Springer, 101-142.

\section{UNDERSTANDING EARTH'S Atmosphere \& Ocean System}

Comprehensive kit with hands-on learning tools

O Can be used at home, in class, or as a lab

10 basic Meteorology and Oceanography topics and over 25 activities

O Can be purchased individually or as a classroom set of 16 (including instructor set)

O Contains reuseable materials designed by AMS and found nowhere else!

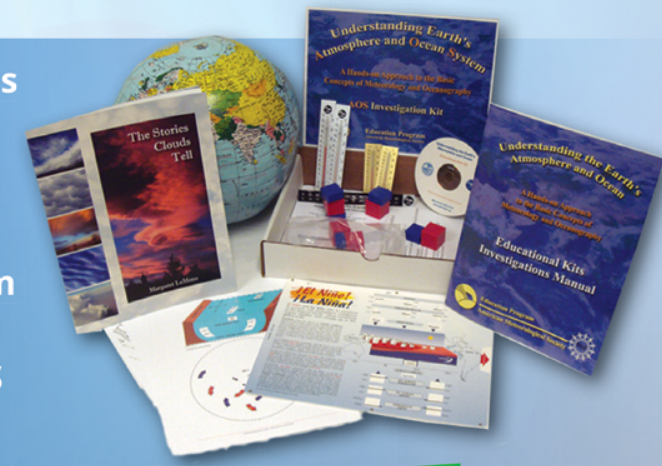

To Order (check, PO, credit card):

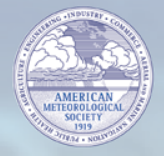

Mail:

Phone:

1-800-824-0405 American Meteorological Society Education Program

Fax: 1200 New York Ave., NW, Ste 500,

$1-800-258-1176$

Washington, DC 20005-3928

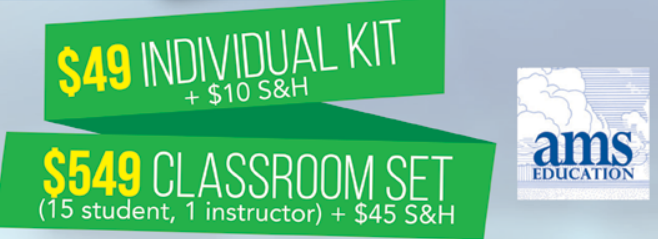




\section{An AMS Member Benefit}

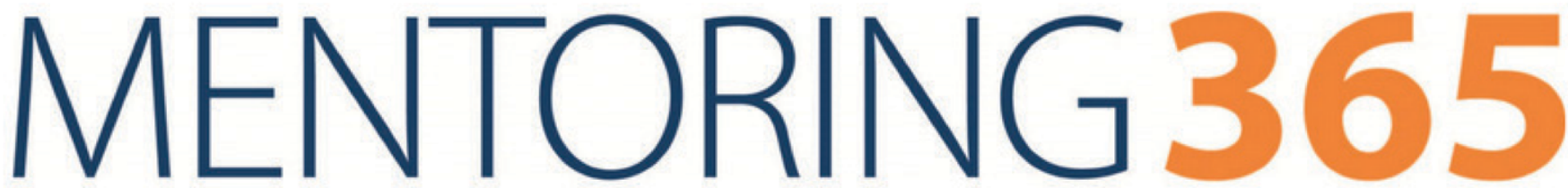

Support the Next Generation of Earth and Space Scientists

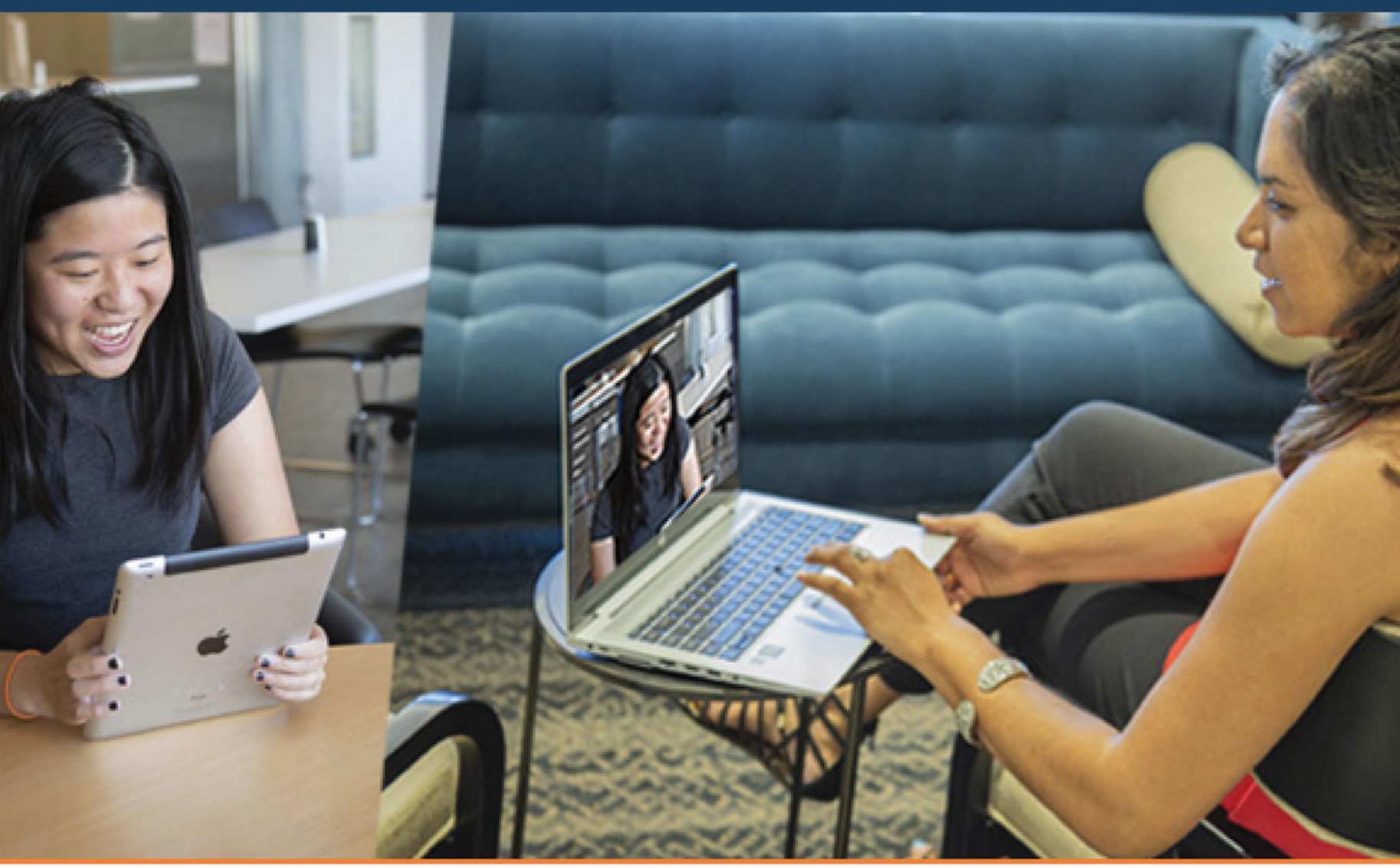

Developed in partnership with Earth and space science organizations, Mentoring365 provides mentors and mentees with structured relationship-building tools to develop and attain focused career goals. 